\title{
Identifikacija prostorno-razvojnih trendova hrvatskih otoka analizom opremljenosti naselja centralnim funkcijama
}

\author{
Veni Marinković \\ Cluster za eko-društvene inovacije i razvoj CEDRA Split, Hrvatska \\ e-mail: marinkovic.veni@yahoo.com
}

\begin{abstract}
SAŽETAK U radu se sagledava opremljenost hrvatskih otočnih naselja centralnim funkcijama te se razmatraju prostorno-razvojni procesi u međuovisnosti o stupnju centraliteta. Ukupno su obuhvaćena 303 naselja na 47 otoka, a centralne su funkcije analizirane u sklopu šest temeljnih skupina: uprava, zdravstvo, obrazovanje, pošta i telekomunikacije, opskrba i financijsko poslovanje, unutar kojih su razmatrani hijerarhijski rangirani sadržaji. Naselja su potom prema (ne)zastupljenosti pojedinih sadržaja razvrstana unutar pet skupina: „bez centraliteta“, „nedostatni centralitet“, „centralitet trećeg ranga“, „centralitet drugog ranga“ i „centralitet prvog ranga“ te su analizirana s obzirom na prostorni položaj, indeks promjene broja stanovnika te indeks starosti. Pokazani su prostorno-razvojni procesi hrvatskih otoka koji se očituju kroz polarizaciju naseljenosti i otočnu litoralizaciju, kao i nepovoljniji trendovi u manjim i slabije funkcionalno opremljenim naseljima.
\end{abstract}

Ključne riječi: otoci, centralne funkcije, centralitet naselja, polarizacija, litoralizacija.

\section{Uvod}

Centralne funkcije obuhvaćaju skup uslužnih djelatnosti tercijarnog i kvartarnog sektora koje osim potrebama vlastitog stanovništva služe i stanovništvu okolnih naselja, a zbog različite koncentracije sadržaja funkcija u prostoru se formira hijerarhija naselja i njihova gravitacijska područja (Malić, 1991.). Koncept centralnih naselja proizlazi iz teorije o centralnim naseljima, nastojeći objasniti veličinu i distribuciju naselja u određenom prostoru. Polazište je te teorije centralno (središnje) mjesto kao naselje koje osigurava opskrbu i usluge za stanovništvo pripadajućeg naselja te njegove šire ili uže okolice. Uže ili šire područje koje potpada pod utjecaj centralnog naselja predstavlja sferu njegovog gravitacijskog utjecaja. Međutim sva centralna naselja nemaju jednaku važnost, što ovisi o broju i vrstama centralnih funkcija u njima, pa se s obzirom na zastupljenost funkcija uobičajeno rangiraju na više stupnjeva (Vresk, 2002.). 
Teorija centralnih naselja kao predmet istraživanja u prostornim znanostima do sada je korištena u brojnim istraživanjima te primijenjena u plansko-strateškim dokumentima, pri čemu autori najčešće izdvajaju gravitacijska područja centralnih naselja te analiziraju opremljenost naselja brojem i vrstama centralnih funkcija. Tako je Laci (1979.) izradio sustav središnjih naselja Međimurja, Malić (1981., 1992.) je analizirao centralne funkcije naselja Središnje Hrvatske i unutrašnje Istre, Njegač (1999.) je istraživao funkcionalnu diferencijaciju i centralnomjesnu organizaciju Hrvatskog zagorja, Novosel-Žic (1986.) je istražila elemente centralnomjesne organizacije otoka Krka, Šakaja (1994.) je analizirala novinsku djelatnost u svjetlu teorije centralnih naselja, Lukić (2012.) je u sklopu tipologije ruralnih područja Hrvatske izradio mrežu središnjih naselja Hrvatske analizirajući broj i vrstu odabranih centralnih funkcija u naseljskom skupu Hrvatske, a Radeljak Kaufmann (2015.) je analizirala opremljenost centralnim funkcijama naselja Dalmacije. U plansko-strateškim dokumentima centralna naselja korištena su za planiranje razvoja harmonične hijerarhijske mreže naselja, s ciljem razvijanja ujednačenijih životnih uvjeta stanovništva. Pri tome se polazi od važnosti naselja za razvoj gravitacijskih područja, kao i njihovog utjecaja na procese urbanizacije i migracija, kao temelja optimalnoga prostornog razmještaja stanovništva te sveukupnoga ravnomjernijeg i usklađenijeg društveno-gospodarskog razvoja (Program prostornog uređenja RH, 1999.).

Otočni prostor Hrvatske u kontekstu opremljenosti naselja centralnim funkcijama do sada nije analiziran kao jedinstvena cjelina. Ipak pregled zastupljenosti pojedinih sadržaja redovito je uvršten u regionalne analize i prikaze pojedinih otoka, pa tako Podgorelec i Klempić Bogadi (2013.) navode i argumentiraju zastupljenost sadržaja zdravstvene, poštansko-telekomunikacijske, financijske, obrazovne te opskrbne funkcije na primjeru malih otočnih zajednica šibenskih otoka, Magaš i Faričić (2000.) u prikazu geografskih osnova razvitka otoka Ugljana iznose njegov sustav i hijerarhiju naselja te odnos prema Zadru, a Magaš, Faričić i Surić (2001.) iznose osvrt na opremljenost centralnim funkcijama elafitskog otočja u međuovisnosti o blizini i gravitaciji Dubrovniku.

Kada je riječ o otočnom prostoru Hrvatske u kontekstu nacionalne mreže središnjih naselja, evidentno je nepostojanje naselja višeg ranga centraliteta od slabijih subregionalnih centara (Lukić, 2012.), odnosno manjih regionalnih središta na njima (Program prostornog uređenja RH, 1999.). Na otočnome prostoru nisu se razvila naselja višeg stupnja centraliteta zbog brojnih i složenih prirodno-geografskih, povijesnih, ekonomskih i demografskih faktora te suvremenih procesa kao što je litoralizacija, rezultirajući smještajem naselja višeg ranga centraliteta Južnog hrvatskog primorja izvan otočnog prostora. Lukić (2012.) tako izdvaja 12 slabijih subregionalnih centara na hrvatskom otočnom prostoru, koji su od sadržaja centralnih funkcija nužno trebali posjedovati osnovnu i srednju školu, dom zdravlja, ljekarnu i stomatologa, prekršajni sud, veći broj prodavaonica mješovitom robom te barem supermarket. Prema administrativnom značaju sva su navedena naselja sjedišta pripadajućih upravnih gradova ili općina. Nadalje izdvaja 17 područnih centara s obveznim sadržajima osnovne škole, ljekarne, stomatologa, u pravilu više prodavaonica te eventualno poslovnice banke, dok su prema administrativnom značaju ta naselja u pravilu sjedišta otočnih općina. Naposljetku izdvaja 32 lokalna centra s obveznim sadržajima 
područne ili osnovne škole, liječnika opće prakse, poštanskog ureda te prodavaonice, dok su samo u rijetkim slučajevima naselja navedenog ranga centraliteta središta otočnih općina.

Predmet istraživanja u radu opremljenost je otočnih naselja sadržajima centralnih funkcija te njihovo rangiranje prema zastupljenosti sadržaja tih funkcija. Naglasak je potom stavljen na razmatranja međusobnog odnosa stupnjeva središnjih otočnih naselja i prostorno-razvojnih procesa kroz analizu demografskih strukturnih i dinamičkih obilježja otočnih naselja. Osnovna je pretpostavka kako se na hrvatskom otočnom prostoru izdvajaju naselja i otoci različitog stupnja opremljenosti centralnim funkcijama te kako opremljenost utječe na suvremene socijalno-demografske procese otoka. Geografski obuhvat istraživanja u radu odnosi se na prostor 47 naseljenih otoka ${ }^{1}$ Hrvatske.

\section{Metodološki okvir istraživanja}

U istraživanju opremljenosti centralnim funkcijama naselja hrvatskih otoka primijenjen je kvantitativni pristup, koji podrazumijeva određivanje vrste i broja centralnih funkcija, odnosno analizu opremljenosti svakog pojedinačnog naselja hijerarhijski rangiranim sadržajima centralnih funkcija, a potom rangiranje naselja s obzirom na (ne)zastupljenost pojedinih sadržaja. Analitički skup čine 303 otočna naselja prema službenoj statistici upotrijebljenoj u Popisu stanovništva 2011. godine, od kojih je za potrebe ove analize izostavljeno osam otočnih naselja bez stalnih stanovnika².

Analizom je obuhvaćeno šest osnovnih skupina centralnih funkcija koje služe zadovoljavanju potreba vlastitog te stanovništva okolnog gravitacijskog područja, a to su: „uprava“, „obrazovanje“, „zdravstvo“, „opskrba“, „financijsko poslovanje“ te „pošta i telekomunikacije“. Navedene skupine uobičajeno se koriste u kvantitativnim analizama opremljenosti naselja centralnim funkcijama (Njegač, 1999.; Lukić, 2012.; Radeljak Kaufmann, 2015.), dok su odabir sadržaja i njihovo hijerarhijsko stupnjevanje određeni s obzirom na specifične ciljeve istraživanja te logiku i zakonsku definiranost unutar pojedinih djelatnosti. S obzirom na to da je cilj istraživanja analizirati opremljenost centralnim funkcijama te rangirati otočna centralna naselja neovisno o kopnenim centrima, pojedine funkcije najvišeg hijerarhijskog ranga nisu uzete u obzir jer navedeni sadržaji nisu prisutni na otocima ${ }^{3}$. Kod funkcije „uprava“ razmatrane

$\mathbf{1}$ To su: Krk, Cres, Lošinj, Susak, Ilovik, Unije, Vele Srakane, Male Srakane, Rab, Pag, Olib, Silba, Premuda, Ist, Molat, Vir, Zverinac, Sestrunj, Rivanj, Rava, Iž, Dugi otok, Ugljan, Ošljak, Pašman, Kornat, Vrgada, Prvić, Kaprije, Žirje, Murter, Krapanj, Zlarin, Drvenik Veli, Drvenik Mali, Čiovo, Šolta, Brač, Hvar, Vis, Biševo, Lastovo, Korčula, Mljet, Šipan, Lopud i Koločep.

2 To su naselja: Stanić i Važminež na otoku Cresu, Dolovo i Sršići na otoku Krku, Humac i Malo Grablje na otoku Hvaru, Oključina na otoku Visu, naselje Sv. Andrija na istoimenom otoku te tri svjetioničarske naseobine: Palagruža, Glavat i Sušac.

3 Radi se o npr. sadržajima prekršajnog, upravnog i trgovačkog suda, visokoškolskim ustanovama, bolnicama i kliničkim centrima. 
su lokacije sadržaja policijskih postaja, ureda državne uprave, općinskih sudova i sjedišta jedinica lokalnih samouprava, koji nisu hijerarhijski uvjetovani, međutim u navedenoj analizi indikator su diferencijacije naselja najvišeg ranga centraliteta. Funkcija „obrazovanje“ analizirana je prema zakonski osnovanoj hijerarhiji sadržaja područnih škola, osnovnih škola te srednjih škola. Kod funkcije „Zdravstvo“ pošlo se od zakonski uvjetovane hijerarhijske podjele na primarnu zdravstvenu zaštitu, odnosno postojanje sadržaja doktora opće medicine, zatim sekundarnu zdravstvenu zaštitu, tj. postojanje određenih specijaliziranih liječnika te postojanje ljekarne u pojedinim naseljima. Funkcija „opskrba“ hijerarhijski je razmatrana kroz analizu lokacija prodavaonica prema tipu i veličini, odnosno postojanja najjednostavnijih i površinom najmanjih trgovina (marketa), zatim površinom većih i prodajnim artiklima raznolikijih supermarketa te najvećih hipermarketa. Kod funkcije „financijsko poslovanje“ određeni su sadržaji bankomata, poslovnica banaka te poslovnica FINA-e, dok je kod funkcije „pošta i telekomunikacije“ razmatrano postojanje sadržaja poštanskog ureda u naseljima. Kada je u pitanju otočni prostor, pored navedenih funkcija od iznimne je važnosti funkcija prometnog povezivanja otoka s kopnom, koja omogućava ostvarivanje redovne komunikacije, razmjene roba, migracije ljudi s otoka na kopno i obrnuto, kao i zadovoljavanje potreba otočnog stanovništva funkcijama koje nisu dostupne na otocima, sveukupno ostvarivanje integriranosti otočnog prostora s matičnim kopnom. Međutim, s obzirom na to da je lokacija sadržaja prometnog povezivanja otoka primarno uvjetovana položajem naselja, kako obalnih tako i onih bližih i okrenutih kopnu, u ovom slučaju ona nije razmatrana jer zbog same vrste prometa kojom se ostvaruje povezivanje (pomorski), radi se o očiglednom favoriziranju obalnih lučkih centara.

Drugi korak istraživanja obuhvaćao je određivanje kriterija za razvrstavanje naselja prema stupnjevima centraliteta. Ti kriteriji uvelike ovise o specifičnostima prostora istraživanja, kao i samim istraživačkim ciljevima. Primjerice Vrišer je (1968.) u centralna naselja uključio ona koja posjeduju najmanje pet funkcija: osmogodišnju školu, zdravstvenu stanicu (ambulantu, ljekarnu), poštu, mjesni ured, trgovinu prehrambenim artiklima ili mješovitom robom. U određivanju hijerarhije centralnih naselja Zapadne Hercegovine Šimunović (1997.) je prilagodio broj i metodologiju određivanja stupnjeva centraliteta predmetnom području, pa tako izdvaja pet razreda. Naseljima s nedostatnim centralitetom smatra sva ona koja ne posjeduju trgovinu mješovitom robom i područnu školu, dok naselja s centralitetom rangira u četiri stupnja, pri čemu kao kriterije koristi funkciju opskrbe, analizirajući lokacije specijaliziranih trgovina (npr. trgovina poljoprivrednim potrepštinama, odjećom i obućom), zatim različite profesionalne usluge (frizer i brijač, autoservis, servis kućanskih uređaja), kulturne ustanove (kino, kazalište) te vjerske ustanove (župni ured, biskupija). Radeljak Kaufmann (2015.) u analizi opremljenosti centralnim funkcijama naselja Dalmacije, osim naselja koja ne posjeduju niti jedan sadržaj funkcija te naselja jače opremljena centralnim funkcijama, izdvaja pet stupnjeva. Pri tome kao faktore prelaska naselja u viši stupanj koristi broj i hijerarhijski rang pojedinih sadržaja funkcija. Glamuzina i Glamuzina (1998.) pak metodom ankete određuju centralitet jedne jedinice lokalne samouprave, pri čemu centralne funkcije dijele na one najnižeg reda (osnovna škola, pošta, ambulanta, mjesni ured, kupnja namirnica), srednjeg reda (srednja škola, kino, općinski sud, banka, osiguranje, kupnja odjeće, obuće 
i namještaja), višeg reda (kupnja nakita, okružni sud, turističke funkcije) i najvišeg reda (bolnice, visoka učilišta, kazališta).

Kod određivanja centraliteta naselja otočnog prostora Hrvatske određeno je pet stupnjeva centraliteta naselja:

- „bez centraliteta“ - naselja koja ne sadrže niti jedan sadržaj osnovnih funkcija

- „nedostatni centralitet“ - naselja koja sadrže jedan do dva sadržaja, i to: poštanski ured i/ili market

- „centralitet trećeg ranga“ - naselja koja sadrže tri do četiri sadržaja, i to: market i/ili poštanski ured i/ili područnu školu i/ili bankomat i/ili doktor opće medicine

- „centralitet drugog ranga“ - naselja koja sadrže minimalno pet sadržaja, ali barem dva sadržaja višeg hijerarhijskog ranga u odnosu na prethodnu skupinu, i to: supermarket, poštanski ured, poslovnicu banke, osnovnu školu, specijaliziranog liječnika te sjedište jedinice lokalne samouprave te

- „centralitet prvog ranga“ - naselja koja sadrže svih šest sadržaja centralnih funkcija, ali barem tri sadržaja višeg ranga u odnosu na prethodnu skupinu te barem jedan dodatni sadržaj iz funkcije „uprava“, osim sjedišta jedinice lokalne samouprave.

Radi daljnje analize prostorno-razvojnih trendova otočna su naselja s obzirom na prostorni položaj diferencirana na obalna i unutarnja, temeljem lokacije naselja na obali ili u unutrašnjosti otoka. Od 303 analizirana naselja njih 149 definirano je kao unutrašnja, dok su 154 naselja određena kao obalna.

Određivanje lokacija sadržaja centralnih funkcija provedeno je u razdoblju od 25. svibnja do 1. lipnja 2016. godine, prema službenim podacima pripadajućih institucija, ustanova i uslužnih sadržaja, i to analizom registara, baza podataka te službenih internetskih stranica.

\section{Rezultati istraživanja}

Razmatranje utjecaja opremljenosti naselja centralnim funkcijama na prostorno-razvojne procese hrvatskih otoka provedeno je analizom distribucije sadržaja centralnih funkcija, zatim rangiranjem naselja prema opremljenosti centralnim funkcijama te analizom demografskih pokazatelja (indeks promjene broja stanovnika 2011./2001. te indeks starosti stanovništva 2011. godine) u međuovisnosti o stupnju centraliteta i prostornom položaju naselja.

\subsection{Distribucija sadržaja centralnih funkcija}

Polazište u stupnjevanju otočnih naselja prema centralitetu predstavlja inventarizacija odabranih sadržaja centralnih funkcija. Njihova je distribucija pokazala kako je sadržaj marketa iz skupine „opskrba“ zabilježen u najvećem broju otočnih naselja, odnosno taj sadržaj pokazao je najslabiji centralitet. Od ukupno 303 u njih 162, odnosno 54\% locirana je trgovina mješovitom robom. Lukić (2012.) je u istraživanju iz 
2003. godine pokazao kako 42,6\% cjelokupnog naseljskog skupa Republike Hrvatske ima prodavaonicu osnovnom robom, odnosno ta je funkcija pokazivala nešto izraženiji centralitet u odnosu na dobiveni rezultat otočnih naselja. Razlog tomu potrebno je sagledati u fizičkoj odvojenosti otoka morem i nemogućnosti ostvarivanja cjelovitosti gravitacijskog područja te funkcije. S obzirom na to da otoci predstavljaju tip prirodno zatvorenog prostora, gravitacijski utjecaj te funkcije ograničenog je prostornog djelovanja i obuhvata u odnosu na kopnene prostore. Podgorelec i Klempić Bogadi (2013.) istražujući male hrvatske otoke zaključuju kako trgovina na otocima ima malo, a ponuda artikala u njima ograničena je uglavnom na živežne namirnice i osnovne potrepštine. Ispitujući stavove lokalnog stanovništva, zaključuju kako su stanovnici uglavnom nezadovoljni izborom robe i cijenama, zbog nepostojanja konkurencije i malog broja kupaca, što uvjetuje količinu i cijenu robe jer je u nju uračunata i cijena prijevoza s kopna. Ponuda u trgovinama na malim hrvatskim otocima uvelike ovisi o broju stanovnika, ali i turista u vrijeme sezone. Bez obzira na manjkavosti trgovačkih sadržaja na malim otocima, postojanje barem jedne lokalne trgovine iznimno je važno za zajednicu jer daje osjećaj sigurnosti i djelomične samostalnosti te smanjuje osjećaj potpune ovisnosti o kopnu.

Idući prema zastupljenosti sadržaj je poštanskog ureda, koji je imalo 106, odnosno $35 \%$ svih otočnih naselja. U otočnim zajednicama, posebice u prošlosti kada je fizička povezanost s kopnom i ostalim otocima bila znatno ograničenija, poštanski je ured bio među najvažnijim sadržajima jer se gotovo sva privatna i poslovna komunikacija odvijala pismima (Podgorelec i Klempić Bogadi, 2013.). Međutim danas kada se smanjila važnost pisane pošte, poštanski uredi dobili su neke dodatne funkcije kao što je mogućnost obavljanja novčanih transakcija i plaćanja računa, koje je na malim otocima moguće obaviti jedino u pošti. Ipak mnogi su poštanski uredi u malim otočnim naseljima ograničenih funkcija i radnog vremena (u pojedinim slučajevima na dva do četiri sata dnevno ili na određene radne dane u tjednu), stoga je moguće zaključiti kako taj sadržaj u potpunosti ne zadovoljava potrebe lokalnog stanovništva s obzirom na predviđene funkcije.

Rezultati za sadržaje iz funkcije „financijsko poslovanje“ pokazuju kako je 69 otočnih naselja (22,7\%) imalo bankomat, 27 (8,9\%) je imalo poslovnicu banke, dok je poslovnicu FINA-e imalo tek 16 otočnih naselja (5,2\%). Razmotri li se prostorna distribucija tog sadržaja, može se zaključiti kako je poslovnica FINA-e bila prisutna isključivo na određenim većim otocima: Krku (2), Cresu (1), Lošinju (1), Rabu (1), Pagu (2), Murteru (1), Hvaru (1), Braču (2), Visu (1), Korčuli (3) i Lastovu (1).

Distribucija sadržaja iz funkcije „obrazovanje“ pokazuje kako je 65 otočnih naselja imalo područnu školu te dodatna 34 naselja potpunu osnovnoškolsku razinu obrazovanja, dok je samo 15 otočnih naselja imalo instituciju srednjoškolskog obrazovanja. Nepostojanje odgojnih i obrazovnih institucija jedan od najvećih nedostataka otočnog života, koji prisiljava djecu na svakodnevno putovanje na kopno. Naime na malim hrvatskim otocima prisutan je višedesetljetni odlazak djece i mladih na školovanje u kopnena središta, nerijetko već u ranim fazama školovanja, kao prethodnica trajnog iseljenja. Zbog manjka ili nepostojanja adekvatne infrastrukture za 
skrb o djeci (jaslice i vrtići), ali i obrazovnih institucija, kao i slabosti obrazovnog procesa u malim otočnim školama, nerijetko su s otoka prisiljene iseliti mlade obitelji. Nepostojanje školskih ustanova na otocima te istovremeno nemogućnost dnevne cirkulacije u škole na kopno temeljni je ograničavajući čimbenik ostanka mlađih obitelji na otocima, kao i doseljavanja obitelji s djecom školske dobi. Postojanje škola u otočnim zajednicama značajno je ne samo s obrazovnog aspekta nego i s društvenog jer je to simbol života i mogućnosti opstanka (Podgorelec i Klempić Bogadi, 2013.). Skračić (1994.) ističe kako je, kada je u pitanju otočno školstvo, potrebno krenuti od načela da škola na otoku mora djelovati bez obzira na broj djece, pa čak i onda kad ih uopće nema. Kad ih nema, autor argumentira, to je garancija da će ih biti te dodaje da je škola jedina institucija na otoku koja može preuzeti brigu o svim kulturnim i informativnim potrebama otočana.

Rezultati sadržaja funkcije „zdravstvo“ pokazali su kako je 58 (19\%) otočnih naselja imalo najniži nivo primane zdravstvene zaštite, odnosno doktora opće medicine, a samo 37 naselja imalo je neki od oblika specijaliziranih liječnika (najčešće zubara, ginekologa i pedijatra). Uslugu ljekarne imalo je tek 38 otočnih naselja. Kvaliteta zdravstvene zaštite znatno se razlikuje na otocima ovisno o njihovoj veličini, broju stanovnika, udaljenosti od kopna te gospodarskoj i turističkoj razvijenosti (Babić, Lajić i Podgorelec, 2004.). Zdravstvena je zaštita, posebice na manjim i izoliranijim otocima, često dostupna samo povremeno, i to prema stalnom rasporedu obilaska liječnika. Specijalističko-konzilijarna zdravstvena zaštita i bolničko liječenje osigurano je u bolnicama u kopnenim centrima, a manjim dijelom u specijalističkim ambulantama domova zdravlja na većim otocima, najčešće povremenim dolascima liječnika specijalista. Dio stacionarne zdravstvene zaštite provodi se u stacionarima otočnih domova zdravlja ili u specijalnim bolnicama (npr. na Rabu, Ugljanu i Korčuli).

Centralna funkcija „uprava“ analizirana je prema četirima pojedinačnim funkcijama: središte jedinice lokalne samouprave, policijska postaja, ured državne uprave i općinski sud. Na 47 naseljenih otoka uspostavljeno je 46 jedinica lokalne samouprave. Ostale pojedinačne funkcije iz te skupine odabrane su s ciljem ukazivanja na upravno središte pojedinog otoka. Ukupno je na otocima bilo deset policijskih postaja, deset ispostava ureda državne uprave te sedam općinskih sudova. U pravilu je funkcija uprave na otocima organizirana tako da su na pojedinim većim otocima uspostavljena upravna središta, najčešce u najvećem naselju, u kojem su locirane sve upravne funkcije kojima gravitira ostatak otoka i/ili susjedni otoci, dok pojedini otoci upravno gravitiraju kopnenim centrima (slika 1). 
Slika 1.

Distribucija sadržaja centralnih funkcija otočnih naselja

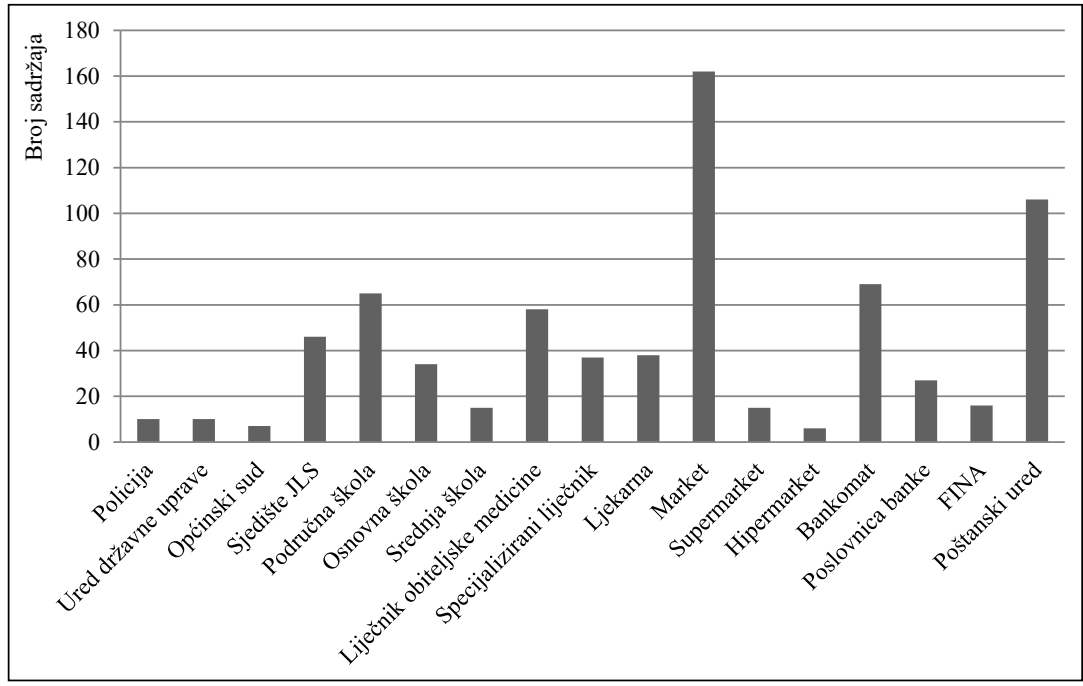

Izvor: prema obradi autora

\subsection{Otočna naselja prema stupnjevima centraliteta}

Otočna naselja rangirana su s obzirom na postojanje zadanog broja, vrste i hijerarhijskog ranga sadržaja funkcija u pet skupina. Od ukupno 303 naselja njih 118, odnosno 38,9\% nije imalo niti jedan sadržaj centralnih funkcija, odnosno u potpunosti je gravitiralo nekom drugom naselju. Skupini „nedostatni centralitet“, tj. onih naselja koja su imala jedan ili dva sadržaja (najčešće market i/ili poštanski ured) pripalo je 89 naselja, tj. 29,4\% svih naselja. Prema tim pokazateljima, više od dvije trećine svih otočnih naselja bilo je podkapacitirano centralnim funkcijama, a njihovo stanovništvo u zadovoljavanju osnovnih potreba gravitiralo je drugom, funkcionalno opremljenijem otočnom i/ili kopnenom naselju. Lukić (2012.) je pokazao kako su od ukupno 6.620 ruralnih naselja Hrvatske njih 5.804, odnosno 87,7\% svih ruralnih naselja, bila slabije funkcionalno opremljena ili bez funkcija, dok njih 4.788, ili 72,3\%, izuzev eventualno prodavaonice, nisu imala niti jednu drugu funkciju. Razlog nešto manjem udjelu te skupine kod otočih naselja potrebno je tražiti u temeljnom obilježju otoka kao prirodno zatvorenih prostora, kod kojih je zbog postojanja fizičkog ograničenja morem utjecaj centralnih funkcija, prvenstveno onih nižeg hijerarhijskog ranga, ograničen na prostor matičnog otoka. Lukić (2012.) nešto viši udio centralnih naselja u Dalmaciji i Južnom hrvatskom primorju, a time i na otocima, objašnjava mediteranskom urbanom tradicijom, koja ima odraz u suvremenoj naseljskoj mreži malih gradova, te procesu litoralizacije kroz funkcionalno jačanje obalnih, populacijski većih naselja. Skupini „centralitet trećeg ranga“ pripada 50 naselja, dok je naseljima iz skupine „centralitet drugog ranga“ pripalo 36 otočnih naselja. Skupini naselja najvišeg ranga centraliteta, odnosno onih s minimalno šest funkcija pripadalo je deset otočnih naselja (slika 2). 
Slika 2.

Distribucija otočnih centralnih naselja

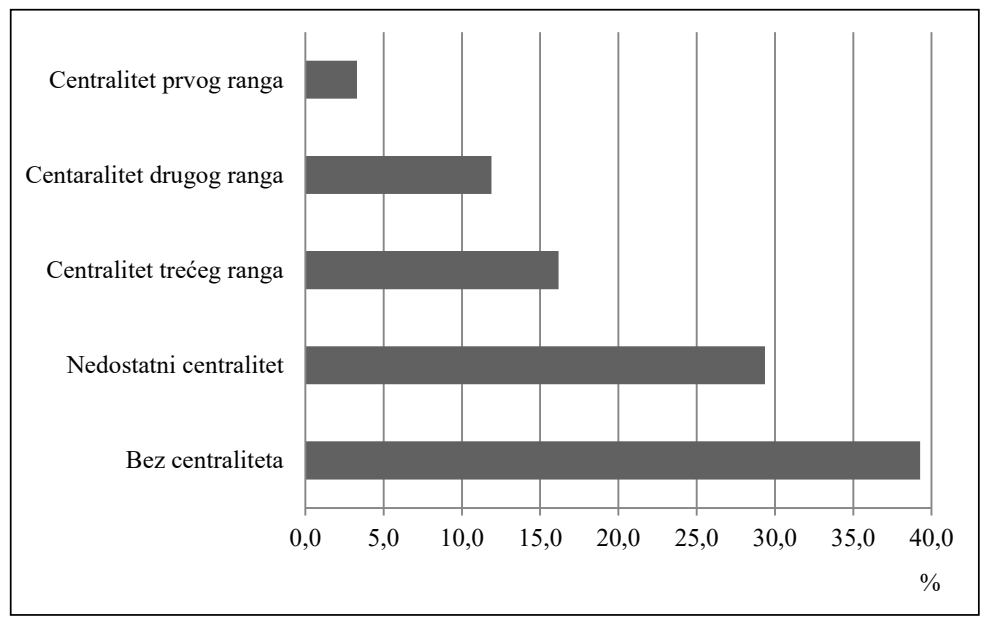

Izvor: prema obradi autora

Prostorna distribucija otočnih naselja prema stupnjevima centraliteta pokazuje kako se u načelu na svakom većem otoku, neovisno o broju jedinica lokalne samouprave, ističe jedno naselje najvišeg stupnja centraliteta. Iznimke su otoci Pag i Hvar. Na otoku Pagu razvijaju se dva naselja najvišeg hijerarhijskog ranga, Pag i Novalja, kao posljedica kontaktnog položaja tog otoka između Kvarnera i Dalmacije te kompleksnosti historijsko-geografskog razvitka otoka tijekom prošlosti, ali i u suvremenom razvoju (Faričić, 2003.). Na otoku Hvaru zastupljena su dva naselja najvišeg ranga centraliteta, Hvar i Stari Grad, primarno zbog podjednake zastupljenosti upravnih funkcija u njima, iako populacijsko i gospodarsko središte predstavlja naselje Hvar.

\subsubsection{Kvarnerska otočna skupina prema centralitetu naselja}

Unutar kvarnerske otočne skupine izdvajaju se tri otočna centra najvišeg ranga, a to su naselja Krk, Mali Lošinj i Rab. Središte otoka Krka istoimeno je naselje Krk, a osim što se ističe kao populacijsko težište otoka, sadrži sve predviđene funkcije iz skupine „uprava“, kojima se izdvaja kao funkcionalno središte otoka. Ostala općinska središta otoka, Baška, Malinska, Omišalj, Punat i Vrbnik, pripadaju naseljima iz skupine „centraliteta drugog ranga“ zbog nedostatka sadržaja upravne i obrazovne funkcije. Jedino unutarnje naselje, ujedno i općinsko središte, Dobrinj pripada skupini „centralitet trećeg ranga" zbog nedostatka osmogodišnje škole (postoji samo područna škola s četirima nižim razredima) te poslovnice banke. Novosel Žic (1986.) također izdvaja tri stupnja centralnih naselja tog otoka, s naseljem Krkom kao vodećim, koji svojim funkcijama okuplja prostor čitavog otoka u jedinstveno gravitacijsko područje. U cresko-lošinjskoj otočnoj skupini izdvaja se naselje Mali Lošinj kao funkcionalno i upravno središte otoka Lošinja, Ilovika, Suska, Unija, Malih i Velih Srakana te 
središnjeg i južnog dijela otoka Cresa. Sjeverni pak dio otoka Cresa gravitira istoimenom naselju, ujedno upravnom središtu Grada Cresa, međutim funkcionalno slabije opremljenom ostalim upravnim i obrazovnim funkcijama, stoga pripadajuće stanovništvo uglavnom gravitira ili susjednom Krku ili Malom Lošinju. Skupini „centralitet trećeg ranga“ pripadaju naselja Ilovik, Susak i Unije na istoimenim otocima, koji od funkcija sadrže tek one osnovne: područnu školu, market i poštanski ured. Otok Rab sadrži sve analizirane upravne te ostale sadržaje, koji služe za zadovoljavanje potreba stanovništva grada Raba te općine Lopar, a na njemu se izdvaja naselje Rab s najvišim rangom centraliteta (slika 3).

Slika 3.

Centralna naselja Kvarnerske i Sjevernodalmatinske otočne skupine

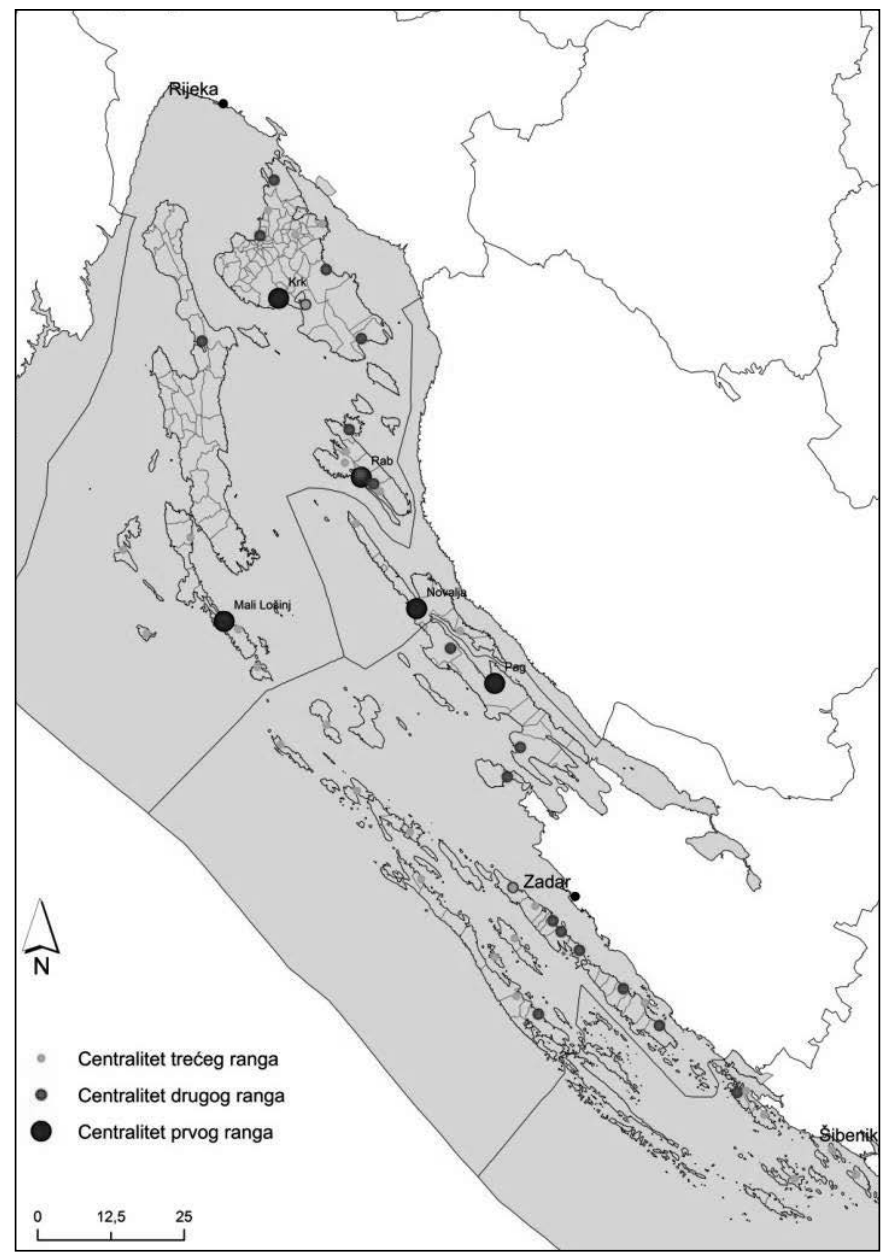

Izvor: prema obradi autora 


\subsubsection{Dalmatinska otočna skupina prema centralitetu naselja}

Sjevernodalmatinska otočna skupina specifična je po tome što se u njoj, izuzev naselja Pag i Novalja, ne izdvaja niti jedno naselje najvišeg hijerarhijskog ranga. Razlog je tomu blizina kopnenih centara Zadra i Šibenika, kojima otoci te skupine gravitiraju, te uvjeti historijsko-geografskog razvoja manjih otoka u sastavu tzv. urboarhipelaga, odnosno otoka kao perifernih dijelova većih kopnenih urbanih sustava (Skračić, 2008.; Faričić, 2012.). Kopnu najbliži otok Ugljan ističe se po sustavu naselja PrekoKali-Sutomišćica, specifičnom centralnom i funkcionalnom žarištu otoka. Njihov je centralitet, međutim, razmjerno slab s obzirom na blizinu Zadra, čiji se funkcionalni utjecaj snažno osjeća na čitavoj ugljanskoj zoni (Magaš i Faričić, 2000.), pa na njemu izostaju neki od analiziranih sadržaja uobičajeni za manje i slabije naseljene otoke, kao što su poslovnica FINA-e, pojedini sadržaji iz funkcije „uprava“ i sl. Osim naselja ugljansko-pašmanske otočne zone, unutar sekundarne skupine centraliteta sjevernodalmatinske otočne skupine uvršteno je upravno i populacijsko središte naselje Sali na Dugom otoku. Čuka (2006.) objašnjava kako je specifičnost tog otoka u odnosu na ostale otoke te skupine njegova udaljenost od kopnenog gravitacijskog centra Zadra, a ujedno i nepovoljniji demografski trendovi, zbog čega se na njemu nisu razvile funkcije najvišeg ranga centraliteta. Manji otoci sjevernodalmatinske skupine Ošljak, Rivanj, Sestrunj, Zverinac i Kornat pripadaju tzv. otocima dvostruke inzularnosti. Riječ je o otocima koji prometno, funkcionalno i administrativno gravitiraju nekoj od otočnih jedinica lokalne samouprave, koja pak dodatno gravitira nekom od kopnenih centara (Taglioni, 2001.). Ti otoci ne sadrže niti jedan od sadržaja analiziranih centralnih funkcija, pa u potpunosti funkcionalno gravitiraju susjednom otočnom centru. Ostale manje otoke Ist, Iž, Molat, Olib, Silbu, Premudu, Ravu, Vrgadu, Kaprije, Krapanj, Zlarin, Žirje i Prvić obilježava zastupljenost tek nekih od temeljnih sadržaja centralnih funkcija najnižeg hijerarhijskog ranga, kao što su područna škola, market, poštanski ured, bankomat, liječnik opće prakse, a navedene funkcije podmiruju tek djelomično potrebe lokalnog stanovništva, tako da su u najvećoj mjeri ti otoci funkcionalno usmjereni prema gravitacijskim kopnenim centrima, kojima ujedno administrativno pripadaju.

Unutar srednjodalmatinske otočne skupine izdvajaju se tri naselja najvišeg ranga centraliteta: Supetar, Hvar i Vis na trima najvećim otocima te skupine. Funkcionalno je središte otoka Brača naselje Supetar, otoka Hvara naselje Hvar, a otoka Visa naselje Vis. Te otoke karakterizira višejezgreni prostorni razvoj, pa se na njima izdvajaju po dva ili više sekundarnih, funkcionalno slabije opremljenih središta. To su Komiža na otoku Visu, Jelsa na otoku Hvaru te Bol, Milna, Postira, Pučišća i Selca na otoku Braču, ujedno središta otočnih jedinica lokalne samouprave, međutim ne sadrže dodatne upravne, srednjoškolske ili zdravstvene funkcije. Osim toga, kao tercijarni centri s obzirom na funkcionalnu opremljenost, na otoku Braču ističe se naselje Nerežišća te na otoku Hvaru naselje Sućuraj. Ta su naselja također središta otočnih lokalnih samouprava, ali su funkcionalno znatno slabije opremljena, pa osim osnovnih sadržaja marketa, poštanskog ureda, liječnika opće prakse i osnovne škole, uglavnom gravitiraju drugim otočnim ili kopnenim centrima. Otok Šolta specifičan je kao „otok bez grada“ (Blagaić Bergman, 2014.). Osim naselja Grohote, koje se izdvaja po potrebnim sadržajima iz skupine „centralitet drugog ranga“, te naselja Sto- 
morska, koje pripada skupini „centralitet trećeg ranga“, za taj je otok specifično da se populacijski, ali i funkcionalno ne izdvajaju naselja koja su znatno opremljenija funkcijama. Razlog slabijoj funkcionalnoj opremljenosti Blagaić Bergman pronalazi u blizini grada Splita te povijesnom razvitku otoka u njegovom administrativnom sastavu. Otoci Drvenik Veliki i Mali upravno i funkcionalno gravitiraju i pripadaju Trogiru, a nešto bolje opremljeniji i populacijski veći Drvenik Veliki pripada skupini „centralitet trećeg ranga“, dok je Drvenik Mali specifičan po gravitacijskom utjecaju susjednom Drveniku Velikom i kopnenom centru Trogiru.

Južnodalmatinska otočna skupina ističe se samo po jednom otočnom centru najvišeg ranga centraliteta, a to je naselje Korčula na istoimenom otoku. Međutim taj otok obilježavaju tri naselja iz skupine „centralitet drugog ranga“, Vela Luka, Blato i Lumbarda. Otoci Mljet i Lastovo imaju po jedno naselje iz skupine „centraliteta drugog ranga“. Otoci iz elafitske skupine Lopud, Šipan i Koločep sadrže tek određene funkcije najnižeg ranga i u većoj mjeri gravitiraju kopnenom centru Dubrovniku (slika 4).

Slika 4.

Centralna naselja srednjodalmatinske i južnodalmatinske otočne skupine

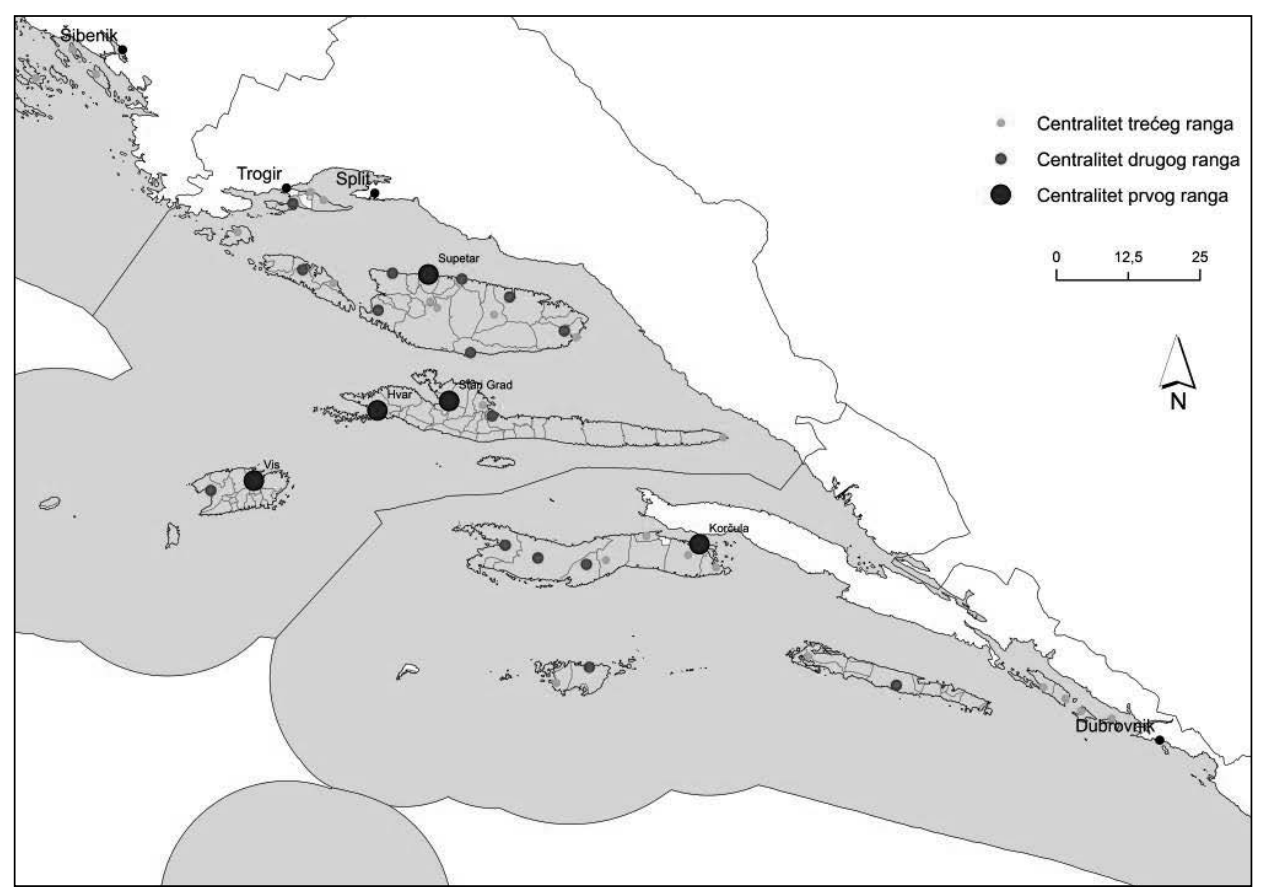

Izvor: prema obradi autora 


\subsection{Prostorno-demografski pokazatelji otočnih naselja prema stupnjevima centraliteta}

Otočni je prostor Hrvatske prema podacima Popisa stanovništva 2011. godine zabilježio ukupno 124.955 stanovnika (Lajić i Mišetić, 2013.). U 118 naselja bez ikakvih postojećih funkcija zabilježeno je tek 7.089 stanovnika, odnosno 5,9\% ukupnog otočnog stanovništva. U skupini naselja „nedostatnog centraliteta“ živjelo je 13,1\% otočne populacije, dok je skupini naselja „centraliteta trećeg ranga“ pripadalo 18\% stanovništva. Nadalje, u skupini naselja „centraliteta drugog ranga“ Živio je udio stanovništva od 38,9\% te naposljetku u deset naselja najvišeg hijerarhijskog ranga živjela je čak jedna četvrtina cjelokupne otočne populacije (slika 5).

Takva distribucija ukazuje na polarizirani prostorni razvoj hrvatskog otočnog prostora, koji se očituje u koncentraciji većine otočnog stanovništva i funkcija u manjem broju centara, dok je preostali dio stanovništva disperziran u manjim naseljima nedostatne ili slabije opremljenosti centralnim funkcijama. Polarizacija kao pojam označava proces okupljanja ljudi i dobara u malom broju izrazito povoljnih točaka u prostoru. U teoriji razvitka pol podrazumijeva identitet mjesta i snagu koji privlače i koji su sposobni utjecati na razvitak okoline. Polarizacija kao proces ima svoju pozitivnu stranu, to jest po efikasnosti koju ima ekonomija razmjera, ali i negativnu, po koncentraciji koja izaziva negativne posljedice, primjerice u uvjetima življenja te opterećivanju prirodnih sustava (Filipić i Šimunović, 1993.).

Slika 5

Distribucija udjela broja naselja i stanovništva prema stupnjevima centraliteta otočnih naselja

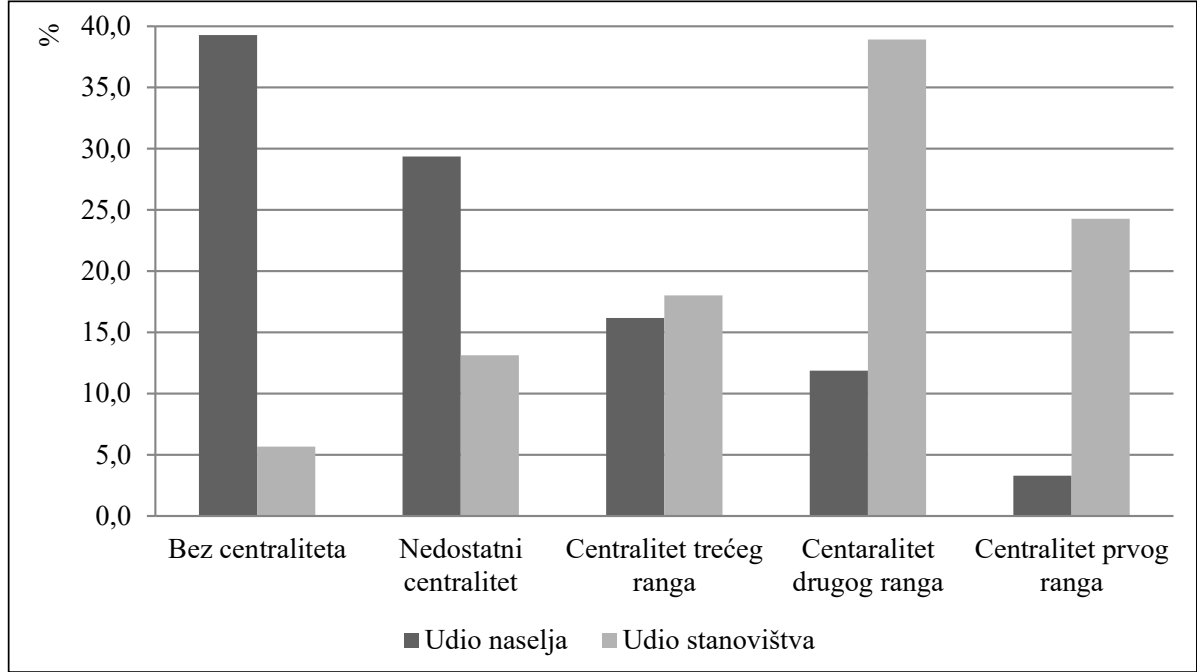

Izvor: prema obradi autora

Polarizirani prostorni razvoj otočnog prostora Hrvatske, koji se reflektira na neravnomjernu naseljenost otoka, preslika je stanja nacionalne i regionalne neravnomjerne naseljenosti, a posljedica je socioekonomskih i demografskih razvojnih tokova. 
Živić (2009.) tako naglašava kako je neravnomjeran razmještaj stanovništva jedan od temeljnih generatora poremećaja u gospodarskom i regionalnom razvoju, koji postaju zamašnjacima znakovitih demografskih, socijalnih, ekonomskih i kulturoloških problema. Problematiku dispariteta u regionalnom razvoju Hrvatske Pejnović (2004.) objašnjava gospodarsko-socijalnom tranzicijom Hrvatske u poslijeratnom periodu, koja se odvijala različitom dinamikom i s prostorno diferenciranim učincima, ovisno o promjeni težišta gospodarskoga razvoja i poredbenim prednostima pojedinih regija. Lajić (1992.) objašnjava kako je otočni prostor upravo u poslijeratnom periodu obilježen intenzivnim depopulacijskim procesom, prvenstveno kao posljedica emigracije otočnog stanovništva u kopnene centre. Iako je otočni prostor oduvijek karakteriziralo iseljavanje kao ključna odrednica demografskih promjena, s izraženim iseljeničkim valovima i periodima tijekom povijesti, upravo je poslijeratni period obilježen najintenzivnijim iseljeničkim valom. Uzroke otočnog iseljavanja nakon Drugog svjetskog rata potrebno je ponajprije sagledati u okvirima dinamičnog razvitka kopnenog dijela zemlje, gdje se ubrzano širila industrijalizacija i zapošljavanje u neprimarnim privrednim sektorima, dok su otoci ostali izvan tih zbivanja i nastavili Živjeti u uvjetima autarkične privrede te u općem gospodarskom konceptu i strategiji državnog razvitka uglavnom zanemarene poljoprivrede i ribarstva. Zbog toga je, za razliku od ranijih iseljeničkih etapa koje su bile spolno selektirane, emigracija u poslijeratnom periodu podjednako obuhvatila obje spolne, kao i sve mlađe dobne skupine, pa su i ukupne demografske posljedice tog iseljeničkog vala bile izraženije od ranijih, a osim toga uvelike su se odrazile na urušavanje tradicionalnog otočnog života te poremećaje u odnosima dobnih skupina (Babić, Lajić i Podgorelec, 2004.). Te promjene upravo su ranije i intenzivnije zahvatile manja naselja i manje otoke, dok je tek manji broj većih otoka i naselja uspio donekle očuvati stabilnije demografske trendove i strukturna obilježja, pa stoga i veći broj i raznolikost sadržaja funkcija.

Nadalje, otočna su naselja podijeljena prema prostornom položaju na obalna i unutarnja. Distribucija naselja prema toj diobi pokazala je kako broj unutrašnjih naselja opada s porastom centraliteta, dok dvjema skupinama najvišeg ranga centraliteta pripadaju većinom ili isključivo obalna naselja. Od ukupno 149 otočnih unutrašnjih naselja više od polovice pripada skupini „bez centraliteta“, a također su brojnija i u skupini „nedostatni centralitet“. Broj unutrašnjih naselja znatno opada od skupine „centralitet trećeg ranga“, u kojoj iznosi tek jednu trećinu ukupnog broja naselja. Skupini „centralitet drugog ranga“ pripada tek sedam unutrašnjih otočnih naselja, dok naseljima najvišeg ranga centraliteta ne pripada niti jedno unutrašnje otočno naselje. S druge strane, znatniji porast broja obalnih naselja u odnosu na unutrašnja primjetan je od skupine „centralitet trećeg ranga“. U toj skupini broj obalnih naselja veći je za čak 75\% u odnosnu na unutrašnja, te je još izraženiji u skupini naselja „centralitet drugog ranga“, gdje je udio obalnih za čak $81 \%$ veći u odnosu na unutrašnja naselja. Sva naselja najvišeg ranga centraliteta prema prostornom položaju pripadaju obalnim naseljima (slika 6). Nalazi takve distribucije ukazuju kako su u suvremenom otočnom razvoju obalna naselja znatno bolje opremljena centralnim funkcijama, čemu ujedno pridonosi i funkcija prometnog povezivanja otoka s kopnom, koja je, kako je već spomenuto, locirana u obalnim naseljima, ali i suvremena gospodarska orijentacija otoka na ljetni, kupališni turizam. Sukladno tomu obalni pojas, a posebice obalna naselja predstavljaju otočno populacijsko težište. 
U unutrašnjim otočnim naseljima prema podacima Popisa iz 2011. godine živjelo je tek 25.098 stanovnika, odnosno jedna četvrtina cjelokupne otočne populacije, a u obalnim 99.857 stanovnika. Prosječno u unutrašnjem otočnom naselju živi tek 168 stanovnika, dok u obalnom 648, pa je prema tom pokazatelju prosječno obalno naselje oko četiri puta mnogoljudnije u odnosu na unutrašnje. Ukupni je broj stanovnika u unutrašnjim naseljima u odnosu na obalna bio veći samo u skupinama „bez centraliteta“ i „nedostatni centralitet“. Razlog tomu je veći ukupni broj unutrašnjih naselja u tim skupinama, što je posljedica koncentracije stanovništva u obalnim otočnim centrima. S druge strane, ukupni broj stanovnika obalnih naselja znatno se povećava od skupine „centralitet trećeg ranga“, pa tako u dvjema skupinama najvišeg centraliteta obalnih naselja živi čak $72 \%$ cjelokupne populacije obalnih otočnih naselja, odnosno 58\% cjelokupne otočne populacije (slika 7). Starc (1992.) spominje kako se u poratnom razdoblju počinje izdvajati nekoliko većih otoka, čije razvojno središte raste na otočnoj obali, privlačeći stanovništvo iz otočne unutrašnjosti, pa tako otočna geografska sredina postaje razvojnom periferijom, dok geografska margina zonom razvoja. Time je pokazan proces litoralizacije na razini otoka, kroz okupljanje i koncentraciju stanovništva, funkcija te društvenog i gospodarskog potencijala u obalnim naseljima. Na primjeru Dugog otoka Čuka (2006.) zaključuje o negativnim posljedicama otočne litoralizacije na prostorni razvoj pojedinih naselja. U prošlosti kada su naselja većinom bila smještena na uzvisinama ili uz plodne zone unutrašnjosti otoka, poradi tranzicije s primarnog na sekundarni i tercijarni sektor djelatnosti ona se postupno spuštaju i šire prema obali, a otočno stanovništvo intenzivno naseljava obalni dio otoka, dok stare seoske otočne jezgre uglavnom zadržavaju stanovništvo starije životne dobi ili odumiru.

Slika 6.

Distribucija otočnih naselja prema rangu centraliteta i prostornom položaju

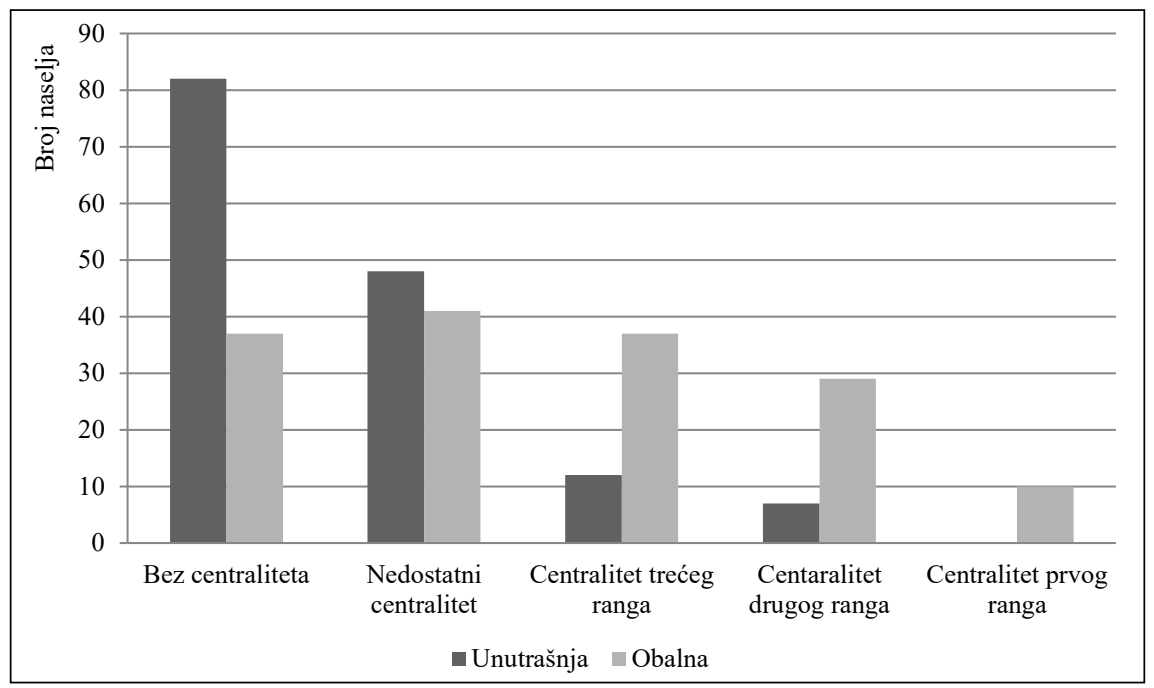


Slika 7.

Distribucija otočnog stanovništva prema rangu centraliteta i prostornom položaju

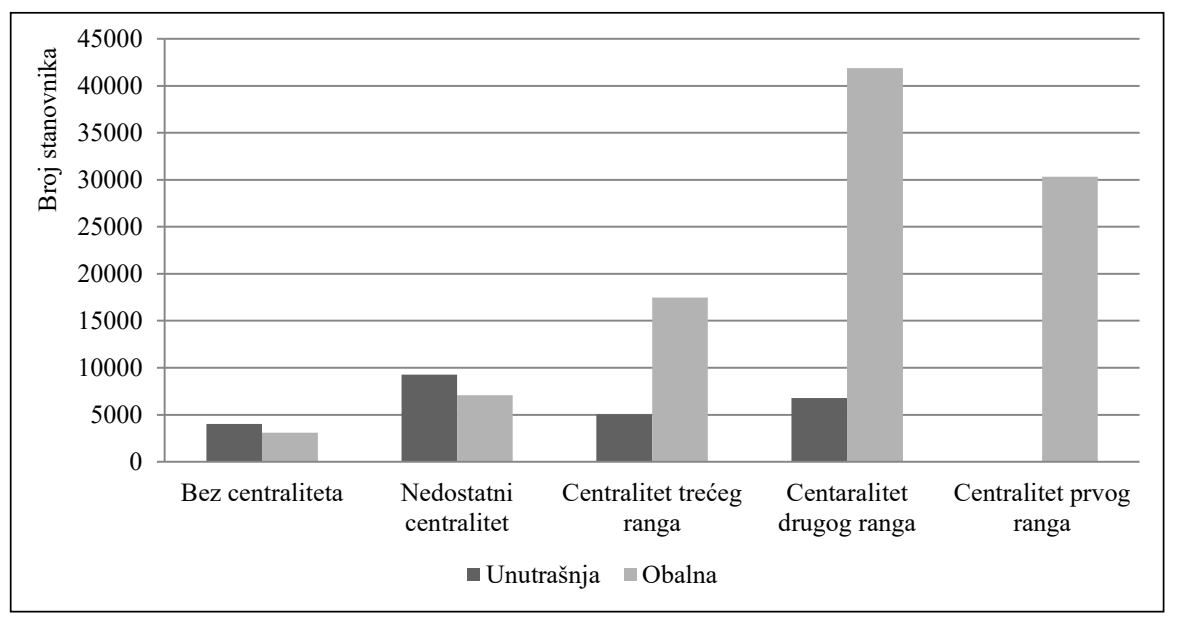

Izvor: prema obradi autora

Nadalje, analiza indeksa promjene broja stanovnika u razdoblju 2001. - 2011. godine pokazuje niže vrijednosti kod unutrašnjih naselja u odnosu na obalna, što znači kako je stanovništvo unutrašnjih naselja u posljednjem međupopisnom razdoblju bilježilo intenzivniju depopulaciju ili sporiji porast broja stanovnika u odnosu na obalna naselja iz iste skupine centraliteta (slika 8). Također, primjetno je kako je najveći porast stanovništva zabilježen kod obalnih naselja iz skupine „bez centraliteta“. Naime navedenim naseljima pripadaju uglavnom manja, obalna turistička naselja, izgrađena većinom kućama za odmor i/ili apartmanima, za koja je značajna pojava tzv. fiktivnog otočnog stanovništva, odnosno stanovništva prijavljenog prebivališta na otocima, ali koji na otocima borave tek sezonski ili povremeno. Pojavu fiktivnog otočnog stanovništva Lajić i Mišetić (2013.) izravno dovode u vezu s izraženim migracijskim saldom, koji je u pozitivnoj korelaciji s brojem stanova za odmor na otocima. Kod takvih naselja ujedno je značajna nedostatna infrastrukturna opremljenost, kao i opremljenost temeljnim funkcijama, kao što su trgovina osnovnim namirnicama, pošta ili bankomat. Radi se primjerice o obalnim naseljima otoka Visa (Rukavac, Milna, Rogačić), Hvara (Milna, Gromin Dolac, Ivan Dolac, Zavala), Lastova (Pasadur, Skrivena Luka, Zaklopatica), Mljeta (Požurska Luka, Saplunara, Ropa), Paga (Kustići, Potočnica, Vidalići, Košljun, Miškovići, Smokvica, Kolanjski Gajac) i Cresa (Beli, Merag, Miholašćica, Porozina, Vantačići, Zidarići). Iznimka je zabilježena u skupini „centralitet trećeg ranga“, u kojoj je indeks promjene broja stanovnika neznatno veći u unutrašnjim naseljima u odnosu na obalna naselja. Tu pojavu moguće je tumačiti kroz demostatističke metodološke osobitosti istraživanja otočnih područja, kod kojih male apsolutne bilježe velike relativne promjene (Lajić i Nejašmić, 1994.). Utjecaj na ukupni rezultat te skupine znatno ponderiraju naselja Nerežišća, Čara i Žrnovo, koja bilježe veći dio porasta, dok čak šest od ukupno 12 naselja iz te skupine bilježe pad broja stanovnika u posljednjem međupopisnom razdoblju. 
Slika 8.

Indeks promjene broja stanovnika 2001./2011. godine otočnih naselja prema rangu centraliteta i prostornom položaju

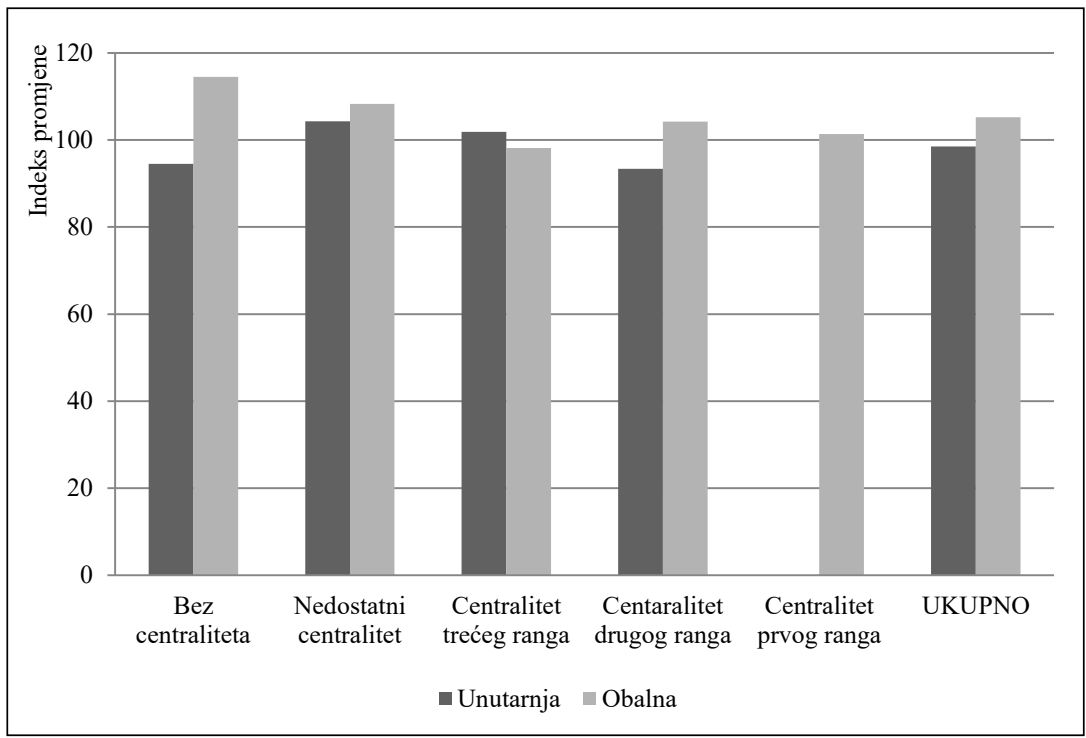

Izvor: prema obradi autora

Analiza indeksa starosti otočnog stanovništva ukazuje na znatno realnije strukturno stanje otočne populacije. Naime ukupni indeks starosti otočnog stanovništva iznosi 190, što znači da na 100 mladih do 19 godina dolazi čak 190 stanovnika starijih od 65 godina, prema čemu otočna populacija pripada iznimno starim populacijama (slika 9). Općenito, indeks starosti otočnog stanovništva opada s porastom ranga centraliteta naselja, što ukazuje na znatno povoljnija strukturna obilježja dobi u naseljima višeg ranga. Najvitalnije je stanovništvo skupine „centralitet prvog ranga“, čiji indeks starosti iznosi 134. S druge strane, najstarije stanovništvo zabilježeno je kod obalnih naselja skupine „nedostatni centralitet“, indeksa starosti od čak 276 te kod unutrašnjih naselja skupine „bez centraliteta“, indeksa starosti 235. Radi se uglavnom o malim naseljima do oko 300 stanovnika, u kojima pretežito boravi stanovništvo starijih dobnih skupina. Dobiveni rezultati dobnog sastava otočnog stanovništva potvrđuju ranije nalaze. Osim što je pokazao kako se u posljednjem međupopisnom razdoblju nastavilo starenje otočnog stanovništva, odnosno udio se mlađih dobnih skupina smanjio uz istodobno povećanja udjela stanovništva u starijim, Nejašmić (2013.) pokazuje kako su središta otočnih općina, koja uglavnom pripadaju najvišim skupinama centraliteta, u nešto povoljnijem položaju u odnosu na ostala naselja, a poglavito u odnosu na male i vrlo male otoke skupno, koje najčešće statistički čine jedno do dva naselja. 
Slika 9.

Indeks starosti otočnog stanovništva 2011. godine prema rangu centraliteta i prostornom položaju

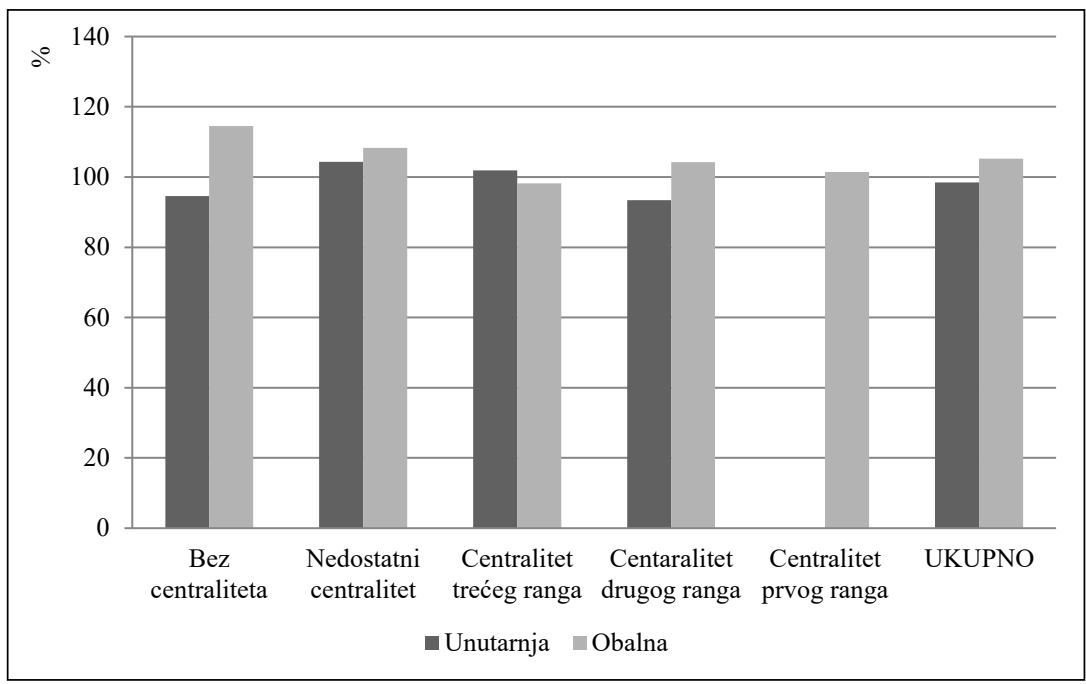

Izvor: prema obradi autora

\section{Zaključak}

Istraživanje opremljenosti otočnih naselja sadržajima centralnih funkcija, njihovo rangiranje prema skupinama centraliteta te analiza međuovisnosti opremljenosti centralnim funkcijama i prostorno-demografskih indikatora ukazali su na odrecene ključne karakteristike i procese suvremenog razvoja otočnog prostora Hrvatske, koje je moguće sagledati u kontekstu razvitka otočnog prostora.

Analizom distribucije sadržaja centralnih funkcija otočnih naselja može se zaključiti kako su pojedina naselja, dijelovi otoka ili čitavi otoci podkapacitirani sadržajima temeljnih funkcija, kao što su opskrba, obrazovanje, zdravstvena zaštita i dr., te u većoj ili manjoj mjeri gravitiraju susjednom otoku ili kopnenom centru. Tu problematiku nužno je razmatrati s aspekta kvalitete života lokalnog stanovništva na otocima i kao jedan od utjecajnijih faktora iseljavanja iz otočnih sredina u kojima nedostaju osnovni sadržaji. S obzirom na to da se načela suvremene regionalne i otočne razvojne politike temelje na omogućavanju jednakosti životnih uvjeta i prilika otočnih i kopnenih sredina te stvaranju prilika za ravnomjerniji regionalni razvoj, opravdano je postaviti pitanje u kojoj je mjeri realno očekivati kako će stanovništvo otočnih naselja ostati ili novo doseliti ukoliko ona ne sadrže neke od temeljnih funkcija.

Nadalje, analizom su pokazana dva temeljna međuovisna procesa koja obilježavaju suvremeni otočni prostorni razvoj, a to su polarizacija i otočna litoralizacija, koji posljedično ostavljaju trag u strukturi suvremene naseljenosti te glavnim demografskim trendovima otoka. S obzirom na strukturu naseljenosti, hrvatske otoke obilježava polariziranost, odnosno koncentracija stanovništva, a posljedično i sadržaja funk- 
cija u manjem broju uglavnom obalnih naselja te disperzija preostalih sadržaja i stanovništva u unutarnjim naseljima. Obalna otočna naselja pokazala su povoljnije i stabilnije demografske trendove i obilježje dobne strukture u odnosu na unutrašnja te istodobno bolju funkcionalnu opremljenost temeljnim sadržajima. S obzirom na navedeno moguće je potvrditi nastavak procesa rasta otočne geografske periferije, ili obalnog dijela kao njegove razvojne jezgre, a otočne geografske jezgre, ili njegove unutrašnjosti kao razvojne periferije. Nastavak i intenzitet tog procesa, koji za posljedicu u prostoru ostavlja smanjivanje te postupno gašenje velikog dijela razvojnog potencijala otoka, ujedno i produbljivanje unutarotočnog razvojnog jaza, uvelike će ovisiti o uključivanju unutrašnjosti u suvremene gospodarske i društvene razvojne tokove, kao što je uključivanje u turističku ponudu otoka, kao i revitalizaciji nekadašnjih glavnih djelatnosti tih dijelova otoka, primarno poljoprivrede. Potencijal za revitalizaciju otočne poljoprivredne proizvodnje i tradicijskog obrtništva, ali i diversifikaciju turističke ponude, prepoznat je s obzirom na rastuću suvremenu potražnju za izvornim i visokokvalitetnim proizvodima s otoka, kao i potražnju za iskustvom sudjelovanja u tradicijskim aktivnostima, primjerice berbi maslina i grožđa, ribolovu, tradicijskim regatama, izgradnji brodova, itd. Prepoznat je također od strane nacionalnih i tijela vlasti EU-a kroz uspostavljene potpore projektima proizvodnje i prerade poljoprivrednih i ostalih proizvoda na otocima. Primjer dobre prakse predstavlja uspostavljena oznaka kvalitete „Hrvatski otočni proizvod“, koju je do sada dobilo više od 200 prehrambenih, kozmetičkih, odjevnih i kulturnih otočnih proizvoda i suvenira, a koji omogućavaju njihovu bolju prepoznatljivost i distribuciju na nacionalnom i međunarodnom tržištu. Također smo svjedoci sve raznolikije i bogatije selektivne turističke ponude na otocima, koja uključuje otočnu kulturnu i prirodnu baštinu, ali i sudjelovanje u otočnim aktivnostima kojima se djelomično valoriziraju dijelovi otoka ili čitavi manji otoci bez značajnije demografske perspektive. Stoga je, ukoliko se navedeni razvojni tokovi nastave, za očekivati da će se rast interesa za otočnim prostorom kao mjestom stanovanja i privređivanja nastaviti, a time i sve veće uključivanje sadašnje razvojne otočne periferije, odnosno manjih unutarnjih naselja u aktualnu gospodarsku i društvenu razvojnu jezgru.

\section{Literatura}

1. Babić, D.; Lajić, I. i Podgorelec, S. (2004). Otoci dviju generacija. Zagreb: Institut za migracije i narodnosti.

2. Blagaić Bergman, M. (2014). Etnološki i kulturnoantropološki doprinos otočnim studijima na primjeru otoka Šolte. Doktorska disertacija, Sveučilište u Zagrebu, Filozofski fakultet.

3. Čuka, A. (2006). Utjecaj litoralizacije na demogeografski razvoj Dugog otoka. Geoadria, 11 (1): 63-92.

4. Faričić, J. (2003). Pag - otok na dodiru geografskih mikrosvjetova. Geografija. hr. http://www.geografija. hr/hrvatska/pag-otok-na-dodiru-geografskih-mikrosvjetova/. (Pregledano 20.12.2015.)

5. Filipić, P. i Šimunović, I. (1993). O ekonomiji obalnih područja: planiranje $i$ upravljanje. Split: Sveučilište u Splitu, Ekonomski fakultet.

6. Glamuzina, M. i Glamuzina, N. (1998). Problem centralnog naselja u općini Gradac. Geoadria, 3: 57-63. 
7. Laci, S. (1979). Centralna naselja Međimurja. Radovi, 14: 19-40.

8. Lajić, I. (1992). Stanovništvo dalmatinskih otoka: povijesne i suvremene značajke depopulacije. Zagreb: Consilium i Institut za migracije i narodnosti.

9. Lajić, I. i Mišetić, R. (2013). Demografske promjene na hrvatskim otocima na početku 21. stoljeća. Migracije i etničke teme, 29 (2): 169-199.

10. Lajić, I. i Nejašmić, I. (1994). Metodološke osobitosti demografskih istraživanja hrvatskog otočja. Društvena istraživanja, 12-13 (4-5): 381-396.

11. Lukić, A. (2012). Mozaik izvan grada: tipologija ruralnih $i$ urbaniziranih naselja Hrvatske. Smobor: Meridijani.

12. Magaš, D. i Faričić, J. (2000). Geographical Elements of the Ugljan Island Development. Geoadria, 5 (1): 42-92.

13. Magaš, D.; Faričić, J. i Surić, M. (2001). Elafitsko otočje fizičko-geografska obilježja u funkciji društveno-gospodarskog razvitka. Geoadria, (6): 31-55.

14. Malić, A. (1981). Centralne funkcije i prometne veze naselja središnje Hrvatske, Zagreb: Geografsko društvo Hrvatske.

15. Malić, A. (1991). Osnovne razvojne karakteristike centralnih naselja nižega reda u Republici Hrvatskoj. Acta Geographica Croatica, 26 (1): 59-64.

16. Malić, A. (1992). Centralne funkcije naselja unutrašnje Istre. Acta Geographica Croatica, 27 (1): 49-56.

17. Nejašmić, I. (2013). Demografsko starenje na hrvatskim otocima. Migracijske $i$ etničke teme, 29 (2): 141-168.

18. Novosel Žic, P. (1986). Neki pokazatelji centralnomjesne organizacije otoka Krka. Radovi, 21: 29-36.

19. Njegač, D. (1999). Funkcionalna diferencijacija naselja i centralnomjesna organizacija Hrvatskoga zagorja. Hrvatski geografski glasnik, 61: 25-36.

20. Pejnović, D. (2004). Depopulacija županija i disparitet u regionalnom razvoju Hrvatske. Društvena istraživanja: časopis za opća društvena pitanja, 4-5 (7273): 701-726.

21. Podgorelec, S. i Klempić Bogadi, S. (2013). Gradovi potopili škoje. Promjene u malim otočnim zajednicama. Zagreb: Institut za migracije i narodnosti.

22. Program prostornog uređenja Republike Hrvatske (1999). Zagreb: Ministarstvo prostornog uređenja, graditeljstva i stanovanja- Zavod za prostorno planiranje.

23. Radeljak Kaufmann, P. (2015). Opremljenost centralnim funkcijama naselja Dalmacije. Godišnjak Titius: godišnjak za interdisciplinarna istraživanja porječja Krke, 8: 83-101.

24. Skračić, V. (1994). Zadarski otoci - natuknice za izradu programa revitalizacije. Društvena istraživanja, 3 (4-5): 485-501.

25. Skračić, V. (2008). Mali otoci - prepoznatljiv znak hrvatske posebnosti na Mediteranu, u: Faričić, J. (Ur.). Otok Rava. Zadar: Sveučilište u Zadru, Razred za prirodne znanosti HAZU, Matica hrvatska - Zadar, Hrvatsko geografsko društvo - Zadar.

26. Starc, N. (1992). Otoci, regije i razvojna politika. Društvena istraživanja, 1 (1): 115-126.

27. Šakaja, L. (1994). Novinska djelatnost u svjetlu teorije centralnih naselja. Hrvatski geografski glasnik, 56 (1): 83-98.

28. Šimunović, V. (1997). Hijerarhija centralnih naselja Zapadne Hercegovine. Acta Geographica Croatica, 32: 125-144. 
29. Taglioni, F. (2011). Insularity, Political Status and Small Insular Spaces. The International Journal of Research into Island Cultures, 5 (2): 45-67.

30. Vresk, M. (2002). Grad i urbanizacija: osnove urbane geografije. Zagreb: Školska knjiga.

31. Vrišer, I. (1968). Centralna naselja u Jugoslaviji, u: Kitoski P. (Ur.). Zbornik na VIII kongres na geografite od SFRJ vo Makedonija. Skopje.

32. Živić, D. (2003). Suvremene tendencije u razvoju stanovništva Hrvatske. Diacovensia: teološki prilozi, 11 (2): 253-279.

\section{Izvori:}

UPRAVA

1. Ministarstvo uprave, Uredi državne uprave po županijama, https://uprava.gov. hr/ustrojstvo/uprava-za-politicki-sustav-drzavnu-upravu-te-lokalnu-i-podrucnuregionalnu-samoupravu/o-drzavnoj-upravi/ustrojstvo-drzavne-uprave-i-struktura-upravljanja/uredi-drzavne-uprave-u-zupanijama/710 (25.5.2016.)

2. Ministarstvo unutarnjih poslova RH, Policijske uprave, http://www.policija.hr/ MainPu.aspx?id=1255 (25.5.2016.)

3. Pravosudna tijela RH, http://sudovi.pravosudje.hr/ (25.5.2016.)

\section{ZDRAVSTVO}

1. Hrvatski zavod za zdravstveno osiguranje, Ugovoreni sadržaji zdravstvene zaštite u RH, http://www.hzzo.hr/zdravstveni-sustav-rh/zdravstvena-zastita-pokrivena-obveznim-zdravstvenim-osiguranjem/ugovoreni-sadrzaji-zdravstvene-zastite$\underline{\mathrm{u}-\mathrm{rh} /}(1.6 .2016$.

\section{OPSKRBA}

1. Konzum, Prodavaonice, https://www.konzum.hr/Prodavaonice (27.5.2016.)

2. Studenac, Popis trgovina, http://studenac.hr/maloprodaja/popis trgovina/ (27.5.2016.)

3. Tommy, Prodajna mjesta, http://tommy.hr/prodajna_mjesta/ (26.5.2016.)

4. LIDL, Trgovine, http://www.lidl.hr/hr/trazilica.htm (26.5.2016.)

5. Trgovina Krk d.d., Marketi, http://www.trgovina-krk.hr/prodavaonice/ (27.5.2016.)

6. NTL, Prodajna mjesta, http://www.ntl.com.hr/prodajna-mjesta (27.5.2016.)

FINANCIJSKO POSLOVANJE

1. Splitska banka, Poslovnice i bankomati, https://www.splitskabanka.hr/poslovnice-i-bankomati/poslovnice (29.5.2016.)

2. Privredna banka Zagreb, Poslovnice i bankomati, https://www.pbz.hr/hr/poduzetnici/mreza-poslovnica-0, (29.5.2016.)

3. Erste Bank, Poslovnice i bankomati, https://www.erstebank.hr/hr/Poslovna mreza $(29.5 .2016$.

4. Raiffeisen Bank, Poslovnice i bankomati, https://www.rba.hr/poslovnice (30.5.2016.)

5. Jadranska banka, Popis polovnih jedinica i bankomata, http://www.jadranskabanka.hr/Default.aspx?sifraStranica=247 (30.5.2016.) 
6. Hrvatska poštanska banka, Poslovnice i bankomati, https://www.hpb.hr/hpbmreza/poslovnice (31.5.2016.)

7. Zagrebačka banka, Poslovnice i bankomati, https://www.google.hr/ search?q=www.zaba.hr+poslovnice (31.5.2016.)

8. FINA, Poslovnice, http://www.fina.hr/poslovnice (29.5.2016.)

POŠTA I TELEKOMUNIKACIJE

1. Hrvatska pošta, Popis poslovnica, http://www.posta.hr/popis-poslovnica-4960 (29.5.2016.)

OBRAZOVANJE

1. Ministarstvo znanosti, obrazovanja i sporta, Popis ustanova u RH s osnovnoškolskim programima, http://public.mzos.hr/Default.aspx?sec=2197 (1.6.2016.)

2. Ministarstvo znanosti, obrazovanja i sporta, Adresar srednjoškolskih ustanova i osnovnih umjetničkih škola, http://public.mzos.hr/Default.aspx?sec=2239 (1.6.2016.) 
Prilog

Popis otočnih naselja s pripadajućim sadržajima centralnih funkcija

\begin{tabular}{|c|c|c|c|c|c|c|c|c|c|c|c|c|c|c|c|c|c|c|}
\hline \multirow{2}{*}{ Otok } & \multirow{2}{*}{ Naselje } & \multicolumn{4}{|c|}{ 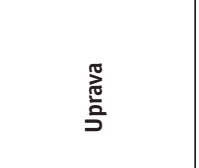 } & \multicolumn{3}{|c|}{ 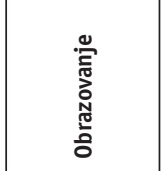 } & \multicolumn{3}{|c|}{ 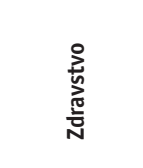 } & \multicolumn{3}{|c|}{ 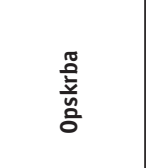 } & \multicolumn{3}{|c|}{ 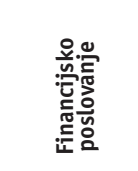 } & \multirow{2}{*}{ 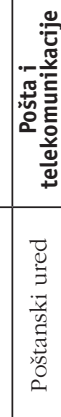 } \\
\hline & & $\begin{array}{l}\frac{\pi}{3} \\
\frac{3}{0} \\
2\end{array}$ & 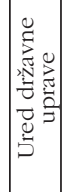 & 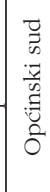 & 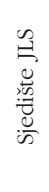 & 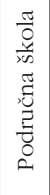 & 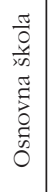 & 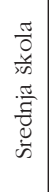 & 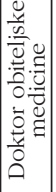 & 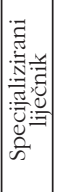 & 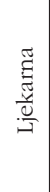 & 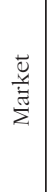 & 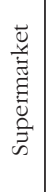 & 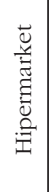 & 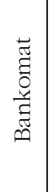 & 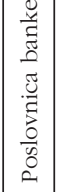 & & \\
\hline \multirow{26}{*}{ Cres } & Beli & & & & & & & & & & & & & & & & & \\
\hline & Cres & & & & + & & + & + & + & + & + & + & & & + & + & + & + \\
\hline & Dragozetići & & & & & & & & & & & & & & & & & \\
\hline & Filozići & & & & & & & & & & & & & & & & & \\
\hline & Grmov & & & & & & & & & & & & & & & & & \\
\hline & Ivanje & & & & & & & & & & & & & & & & & \\
\hline & Loznati & & & & & & & & & & & & & & & & & \\
\hline & Lubenice & & & & & & & & & & & & & & & & & \\
\hline & Mali Podol & & & & & & & & & & & & & & & & & \\
\hline & Martinšćica & & & & & & & & & & & + & & & & & & + \\
\hline & Merag & & & & & & & & & & & & & & & & & \\
\hline & Miholašćica & & & & & & & & & & & & & & & & & \\
\hline & Orlec & & & & & & & & & & & & & & & & & \\
\hline & Pernat & & & & & & & & & & & & & & & & & \\
\hline & Porozina & & & & & & & & & & & & & & & & & \\
\hline & Predošćica & & & & & & & & & & & & & & & & & \\
\hline & Stanićn & & & & & & & & & & & & & & & & & \\
\hline & Stivan & & & & & & & & & & & & & & & & & \\
\hline & Sveti Petar & & & & & & & & & & & & & & & & & \\
\hline & Valun & & & & & + & & & & & & + & & & & & & \\
\hline & Važminežz & & & & & & & & & & & & & & & & & \\
\hline & Vidovići & & & & & & & & & & & & & & & & & \\
\hline & Vodice & & & & & & & & & & & & & & & & & \\
\hline & Vrana & & & & & & & & & & & & & & & & & \\
\hline & Zbičina & & & & & & & & & & & & & & & & & \\
\hline & Zbišina & & & & & & & & & & & & & & & & & \\
\hline
\end{tabular}




\begin{tabular}{|c|c|c|c|c|c|c|c|c|c|c|c|c|c|c|c|c|c|c|}
\hline \multirow{2}{*}{ Otok } & \multirow{2}{*}{ Naselje } & \multicolumn{4}{|c|}{ 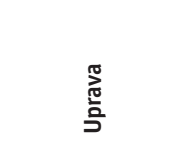 } & \multicolumn{3}{|c|}{ 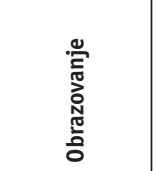 } & \multicolumn{3}{|c|}{$\begin{array}{l}\stackrel{2}{2} \\
\text { 营 } \\
\text { N }\end{array}$} & \multicolumn{3}{|c|}{$\begin{array}{l}\text { 营 } \\
\text { 言 }\end{array}$} & \multicolumn{3}{|c|}{ 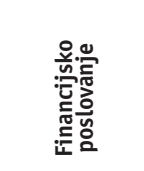 } & \multirow{2}{*}{ 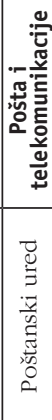 } \\
\hline & & 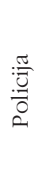 & 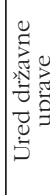 & 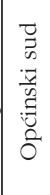 & 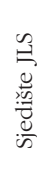 & 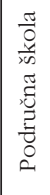 & 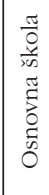 & 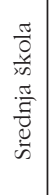 & 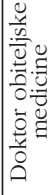 & 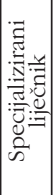 & 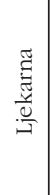 & $\begin{array}{l}\frac{\vec{u}}{y} \\
\frac{\vec{w}}{2}\end{array}$ & 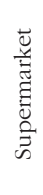 & 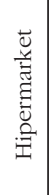 & 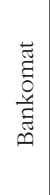 & 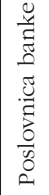 & 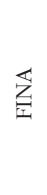 & \\
\hline \multirow{51}{*}{ Krk } & Bajčicíi & & & & $\ldots$ & & & & & & & & & & & | $\ldots$ & & \\
\hline & Brusići & & & & & & & & & & & + & & & & & & \\
\hline & Brzac & & & & & & & & & & & $+\ldots$ & & & & & & \\
\hline & Kornić & & & & & & & & & & & + & & & & & & + \\
\hline & Krk & + & + & + & + & & + & + & + & + & ........ & + & + & ....... & + & + & + & + \\
\hline & Lakmartin & & & & & & & & & & & & & & & & & \\
\hline & Linardićí & & & & & & & & & & & + & & & & & & \\
\hline & Milohnići & & & & & & & & & & & + & & ....... & & 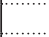 & & \\
\hline & Muraj & & & & & & & & & & & & & & & & & \\
\hline & Nenadići & & & & & & & & & & & $+\ldots$ & & .... & & …. & & \\
\hline & Pinezići & & & & & & & & & & & $+\ldots$ & & & & & & \\
\hline & Poljica & & & & $\cdots$ & & & & & & & & & & & & & \\
\hline & Skrbčići & & & & & & & & & & & $+\ldots$ & & & & & & \\
\hline & $\mathrm{Vrh}$ & & & & & ++ & & & $\ldots \ldots$ & | & a......... & + & & $\ldots$ & & $\ldots$ & & \\
\hline & Žgaljicí & & & & & & & & & & & & & & & & & \\
\hline & Baška & & & & + & $+\ldots$ & 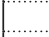 & & $+\ldots$ & 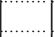 & $+\ldots$ & + & & ....... & ++ & ++ & & + \\
\hline & Batomali & & & & & & & & & & & & & & & & & \\
\hline & Draga Bašćanska & & & & & & & & & & & + & & & & & & + \\
\hline & Jurandvor & & & & & & & & .... & & $\ldots$ & + & & & & & & \\
\hline & Čižííi & & & & & & & & & & & $+\ldots$ & & & & & & \\
\hline & Dobrinj & & & & + & + & & & + & & $\ldots$ & + & & ....... & ++ & & 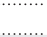 & + \\
\hline & Dolovo* & & & & & & & & & & & & & & & & & \\
\hline & Gabonjin & & & & ... & & & & & & & + & & & & & & \\
\hline & Gostinjac & & & & & & & & & & & + & & & & & & \\
\hline & Hlapa & & & & & & & & & & & & & & & & & \\
\hline & Klanice & & & & & & & & & & & & & & & & & \\
\hline & Klimno & & & & & & & & & & & + & & & & & & \\
\hline & Kras & & & & & & & & & & $\ldots$ & + & & & & & & \\
\hline & Polje & & & & & & & & & & & & & & & & & \\
\hline & Rasopasno & & & & & & & & & & & + & & & & & & \\
\hline & Rudine & & & & & & & & & & & & & & & & & \\
\hline & Soline & & & & & & & & & & & + & & & & & & \\
\hline & Sužan & & & & & & & & & & & + & & & & & & \\
\hline & Sveti Ivan Dobrinjski & & & & & & & & & & & & & & & & & \\
\hline & Sveti Vid Dobrinjski & & & & & & & & & & & + & & & & & & \\
\hline & Šilo & & & & & & & & + & + & + & + & & & + & & & + \\
\hline & Tribulje & & & & & & & & & & & & & & & & & \\
\hline & Žestilac & & & & & & & & & & & & & & & & & \\
\hline & Zupanje & & & & & & & & 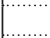 & 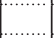 & & & & & & & & \\
\hline & Barušići & & & & & & & & & & & & & & & & & \\
\hline & Bogovići & & & & & + & & & .... & & & & & & & & & \\
\hline & Kremenići & & & & & & & & & & & & & & & & & \\
\hline & Ljutići & & & & & & & & & & & & & & & & & \\
\hline & Malinska & & & & + & ++ & & & + & + & + & + & + & + & + & + & + & + \\
\hline & Maršići & & & & & & & & & & & & & & & & & \\
\hline & Milčetići & & & & & & & & & & & + & & & & & & \\
\hline & Milovéííi & & & & & & & & & & & & & & & & & \\
\hline & Oštrobradić & & & & & & & & & & & & & & & & & \\
\hline & Porat & & & & & & & & & & & + & & & & & & \\
\hline & Radići & & & & & & & & & & & & & & & & & \\
\hline & Sabljici & & & & & & & & & & & & & & & & & \\
\hline
\end{tabular}




\begin{tabular}{|c|c|c|c|c|c|c|c|c|c|c|c|c|c|c|c|c|c|c|}
\hline \multirow{2}{*}{ Otok } & \multirow{2}{*}{ Naselje } & \multicolumn{4}{|c|}{ 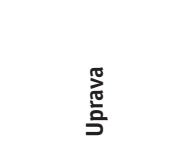 } & \multicolumn{3}{|c|}{ 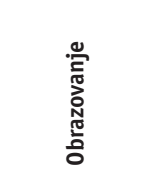 } & \multicolumn{3}{|c|}{ 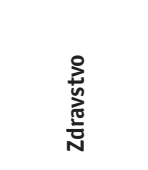 } & \multicolumn{3}{|c|}{ 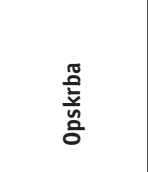 } & \multicolumn{3}{|c|}{ 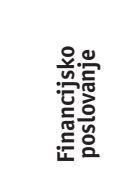 } & \multirow{2}{*}{ 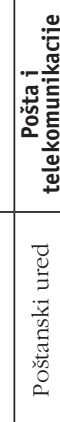 } \\
\hline & & $\begin{array}{l}\frac{\pi}{0} \\
: 0 \\
0 \\
0\end{array}$ & 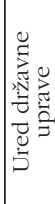 & $\begin{array}{l}\vec{z} \\
\text { क } \\
\frac{\vec{y}}{w} \\
\tilde{0} \\
0 \\
0\end{array}$ & 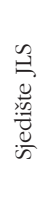 & 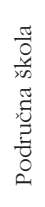 & $\begin{array}{l}\frac{\pi}{0} \\
\frac{0}{x p} \\
\tilde{J} \\
0 \\
0 \\
0 \\
0 \\
0\end{array}$ & 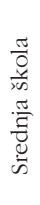 & 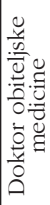 & 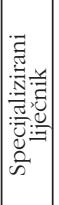 & 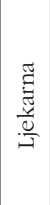 & 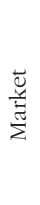 & 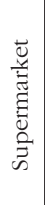 & 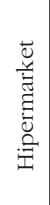 & 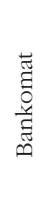 & 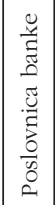 & $\underset{\mathrm{Z}}{\overleftrightarrow{\mathrm{Z}}}$ & \\
\hline \multirow{17}{*}{ Krk } & Sršići* & & & & & & & & & & & & & & & & & \\
\hline & Strilčići & & & & & & & & & & & & & & & & & \\
\hline & Sveti Anton & & & & & & & & & & & & & & & & & \\
\hline & Sveti Ivan & & & & & & & & & & & & & & & & & \\
\hline & Sveti Vid-Miholjice & & & & & & & & & & & + & & & & & & \\
\hline & Turčić & & & & & & & & & & & & & & & & & \\
\hline & Vantačići & & & & & & & & & & & & & & & & & \\
\hline & Zidarići & & & & & & & & & & & & & & & & & \\
\hline & Žgombići & & & & & & & & & & & & & & & & & \\
\hline & Njivice & & & & & & & & & & & + & & & + & + & & + \\
\hline & Omišalj & & & & + & & + & & + & + & + & + & + & & + & & & + \\
\hline & Punat & & & & + & & + & & + & + & + & + & & & + & + & & + \\
\hline & Stara Baška & & & & & & & & & & & + & & & + & & & \\
\hline & Garica & & & & & & & & & & & + & & & & & & \\
\hline & Kampelje & & & & & & & & & & & & & & & & & \\
\hline & Risika & & & & & & & & & & & + & & & 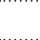 & & & \\
\hline & Vrbnik & & & & + & & + & & + & + & & + & & & + & & & + \\
\hline \multirow{9}{*}{ Lošinj } & Belej & & & & & & & & & & & 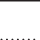 & & & & & & \\
\hline & Cunski & & & & & & & & & & & + & & & 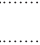 & . & & + \\
\hline & Mali Lošinj & + & + & + & + & & + & + & + & + & + & + & + & & + & + & + & + \\
\hline & Nerezine & & & & & + & & & & & & + & & & + & + & & + \\
\hline & Osor & & & & & & & & & & & + & & & & & & + \\
\hline & Punta Križa & & & & & & & & & & & + & & & & & & \\
\hline & Sveti Jakov & & & & & & & & & & & & & & & & & \\
\hline & Ustrine & & & & & & & & & & & & & & & & & \\
\hline & Veli Lošinj & & & & & + & & & & & & + & & & + & & & + \\
\hline Ilovik & Ilovik & & & & & + & & & & & & + & & & & & & + \\
\hline Male Srakane & Male Srakane & & & & & & & & & & & & & & & & & \\
\hline Susak & Susak & & & & & + & & & & & & + & & & & & & + \\
\hline Unije & Unije & & & & & + & & & & & & + & & & & & & + \\
\hline Vele Srakane & Vele Srakane & & & & & & & & & & & & & & & & & \\
\hline \multirow{8}{*}{ Rab } & Banjol & & & & & & + & + & & & & + & & & + & + & & + \\
\hline & Barbat na Rabu & & & & & + & & & & & & + & & & & & & + \\
\hline & Kampor & & & & & + & & & & & & + & & & & & & + \\
\hline & Mundanije & & & & & + & & & & & & & & & & & & + \\
\hline & Palit & + & & & & & & & + & + & + & + & & & + & & & + \\
\hline & $\mathrm{Rab}$ & & + & + & + & & & & & & + & + & + & & + & + & + & + \\
\hline & Supetarska Draga & & & & & + & & & + & & & + & & & + & & & + \\
\hline & Lopar & & & & + & & & & + & & + & & & & + & + & & + \\
\hline
\end{tabular}




\begin{tabular}{|c|c|c|c|c|c|c|c|c|c|c|c|c|c|c|c|c|c|c|}
\hline \multirow{2}{*}{ Otok } & \multirow{2}{*}{ Naselje } & \multicolumn{4}{|c|}{ 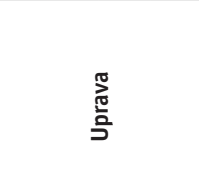 } & \multicolumn{3}{|c|}{ 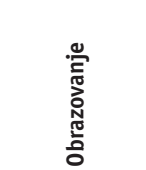 } & \multicolumn{3}{|c|}{ 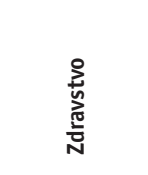 } & \multicolumn{3}{|c|}{ 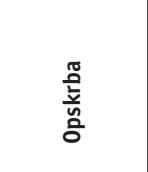 } & \multicolumn{3}{|c|}{ 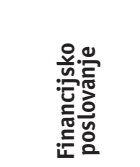 } & \multirow{2}{*}{ 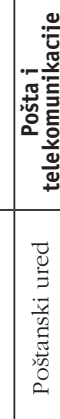 } \\
\hline & & $\begin{array}{l}\frac{\pi}{\vec{J}} \\
: \overline{0} \\
0\end{array}$ & 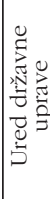 & 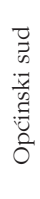 & 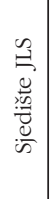 & 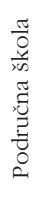 & $\begin{array}{l}\frac{\pi}{0} \\
\frac{d}{x p} \\
\tilde{3} \\
5 \\
0 \\
0 \\
0 \\
0\end{array}$ & 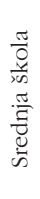 & 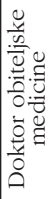 & 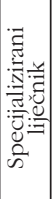 & 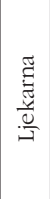 & 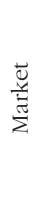 & 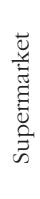 & 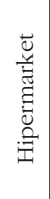 & 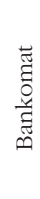 & 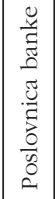 & $\underset{\mathrm{z}}{\overleftrightarrow{\mathrm{z}}}$ & \\
\hline \multirow{25}{*}{ Pag } & Caska & & & & & & & & & & & + & & & & & & \\
\hline & Gajac & & & & & & & & & & & + & & & + & & & \\
\hline & Kustići & & & & & & & & & & & & & & & & & \\
\hline & Lun & & & & & + & & & & & & + & & & + & & & + \\
\hline & Metajna & & & & & + & & & & & & + & & & & & & \\
\hline & Novalja & + & + & & + & & + & & + & + & + & + & & & + & + & + & + \\
\hline & Potočnica & & & & & & & & & & & & & & & & & \\
\hline & Stara Novalja & & & & & & & & & & & + & & & & & & \\
\hline & Vidalići & & & & & & & & & & & & & & & & & \\
\hline & Zubovići & & & & & + & & & & & & + & & & & & & + \\
\hline & Bošana & & & & & & & & & & & & & & & & & \\
\hline & Dinjiška & & & & & + & & & & & & & & & & & & \\
\hline & Gorica & & & & & & & & & & & & & & & & & \\
\hline & Košljun & & & & & & & & & & & & & & & & & \\
\hline & Miškovići & & & & & & & & & & & & & & & & & \\
\hline & Pag & + & + & + & + & & + & + & + & + & + & + & & & + & + & + & + \\
\hline & Smokvica & & & & & & & & & & & & & & & & & \\
\hline & Stara Vas & & & & & & & & & & & & & & & & & \\
\hline & Šimuni & & & & & & & & & & & + & & & & & & \\
\hline & Vrčići & & & & & & & & & & & & & & & & & \\
\hline & Vlašići & & & & & + & & & & & & + & & & & & & \\
\hline & Kolan & & & & + & + & & & & & + & + & & & + & & & + \\
\hline & Kolanjski Gajac & & & & & & & & & & & & & & & & & \\
\hline & Mandre & & & & & & & & & & & + & & & & & & \\
\hline & Povljana & & & & + & + & & & + & + & + & + & & & + & & & + \\
\hline \multirow{3}{*}{ Molat } & Molat & & & & & + & & & & & & + & & & & & & + \\
\hline & Zapuntel & & & & & & & & & & & & & & & & & \\
\hline & Brgulje & & & & & & & & & & & & & & & & & \\
\hline Ist & Ist & & & & & & & & + & & & + & & & + & & & + \\
\hline \multirow{2}{*}{ Iž } & Veli Iž & & & & & + & & & + & & & + & & & + & & & + \\
\hline & Mali Iž & & & & & & & & & & & + & & & & & & \\
\hline Olib & Olib & & & & & & & & & & & + & & & & & & + \\
\hline Premuda & Premuda & & & & & + & & & & & & + & & & & & & + \\
\hline Rava & Rava & & & & & + & & & & & & + & & & & & & + \\
\hline
\end{tabular}




\begin{tabular}{|c|c|c|c|c|c|c|c|c|c|c|c|c|c|c|c|c|c|c|}
\hline \multirow{2}{*}{ Otok } & \multirow{2}{*}{ Naselje } & \multicolumn{4}{|c|}{ 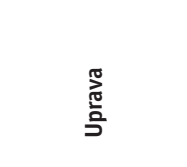 } & \multicolumn{3}{|c|}{ 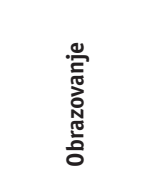 } & \multicolumn{3}{|c|}{ 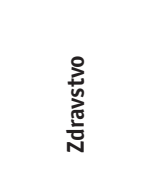 } & \multicolumn{3}{|c|}{$\begin{array}{l}\frac{\pi}{2} \\
\frac{\text { 幺ั }}{0}\end{array}$} & \multicolumn{3}{|c|}{ 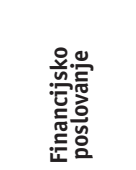 } & \multirow{2}{*}{ 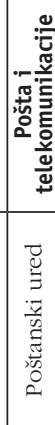 } \\
\hline & & $\begin{array}{l}\frac{\pi}{\tilde{J}} \\
\frac{0}{0} \\
2\end{array}$ & 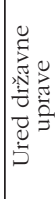 & 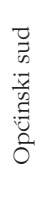 & 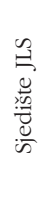 & 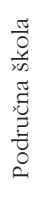 & 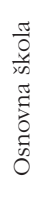 & 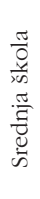 & 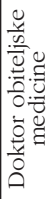 & 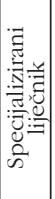 & 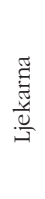 & 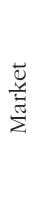 & 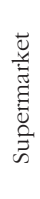 & 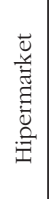 & 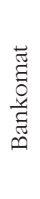 & 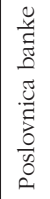 & $\underset{\mathrm{C}}{\overleftrightarrow{\mathrm{C}}}$ & \\
\hline Silba & Silba & & & & & + & & & + & & & + & & & + & & & + \\
\hline \multirow{8}{*}{ Pašman } & Banj & & & & & & & & & & & + & & & & & & \\
\hline & Dobropoljana & & & & & & & & & & & + & & & & & & \\
\hline & Kraj & & & & & & & & & & & + & & & & & & \\
\hline & Mrljane & & & & & & & & & & & + & & & & & & \\
\hline & Neviđane & & & & & & + & & + & + & & + & & & & & & + \\
\hline & Pašman & & & & + & & & & + & & & + & & & + & & & + \\
\hline & Ždrelac & & & & & & & & & & & + & & & & & & + \\
\hline & Tkon & & & & + & + & & & + & & + & + & & & + & & & + \\
\hline Ošljak & Ošljak & & & & & & & & & & & & & & & & & \\
\hline Rivanj & Rivanj & & & & & & & & & & & & & & & & & \\
\hline Sestrunj & Sestrunj & & & & & & & & & & & + & & & & & & + \\
\hline \multirow{7}{*}{ Ugljan } & Lukoran & & & & & + & & & & & & + & & & + & & & + \\
\hline & Poljana & & & & & + & & & & & & & & & & & & \\
\hline & Preko & & & & + & & + & & + & + & + & + & & & + & + & & + \\
\hline & Sutomišćica & & & & & + & & & & & & + & & & & & & \\
\hline & Ugljan & & & & & + & & & & & & + & & & + & & & + \\
\hline & Kali & & & & + & + & & & + & & & + & & & + & & & + \\
\hline & Kukljica & & & & + & + & & & + & & & + & & & + & & & + \\
\hline \multirow{11}{*}{ Dugi otok } & Božava & & & & & + & & & + & & & + & & & & & & + \\
\hline & Brbinj & & & & & & & & & & & & & & & & & + \\
\hline & Dragove & & & & & & & & & & & & & & & & & \\
\hline & Luka & & & & & & & & & & & + & & & & & & \\
\hline & Sali & & & & + & & + & & + & + & + & + & + & & + & & & + \\
\hline & Savar & & & & & & & & & & & + & & & & & & \\
\hline & Soline & & & & & & & & & & & + & & & & & & \\
\hline & Veli Rat & & & & & & & & & & & & & & & & & \\
\hline & Verunić & & & & & & & & & & & & & & & & & \\
\hline & Zaglav & & & & & & & & & & & & & & & & & \\
\hline & Žman & & & & & & & & + & & & + & & & & & & + \\
\hline Zverinac & Zverinac & & & & & & & & & & & + & & & & & & \\
\hline
\end{tabular}




\begin{tabular}{|c|c|c|c|c|c|c|c|c|c|c|c|c|c|c|c|c|c|c|}
\hline \multirow{2}{*}{ Otok } & \multirow{2}{*}{ Naselje } & \multicolumn{4}{|c|}{ 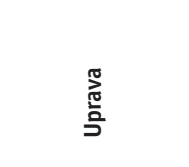 } & \multicolumn{3}{|c|}{ 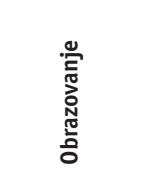 } & \multicolumn{3}{|c|}{ 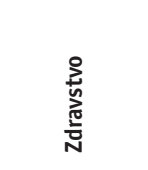 } & \multicolumn{3}{|c|}{ 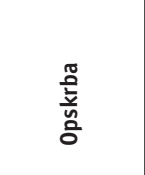 } & \multicolumn{3}{|c|}{ 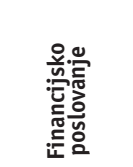 } & \multirow{2}{*}{ 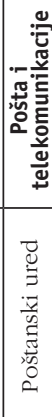 } \\
\hline & & $\begin{array}{l}\frac{\pi}{0} \\
\frac{\pi}{0} \\
2 \\
2\end{array}$ & 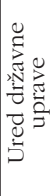 & 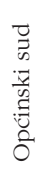 & 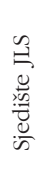 & 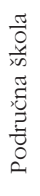 & $\begin{array}{l}\frac{\pi}{0} \\
\frac{4}{20} \\
\tilde{3} \\
5 \\
0 \\
0 \\
0 \\
0\end{array}$ & 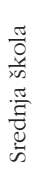 & 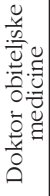 & 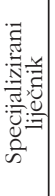 & 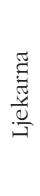 & 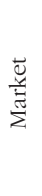 & 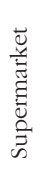 & 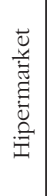 & 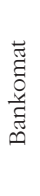 & 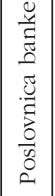 & $\underset{z}{\overleftrightarrow{z}}$ & \\
\hline Vrgada & Vrgada & & & & & + & & & & & & + & & & & & & \\
\hline Vir & Vir & & & & + & + & & & + & + & + & + & + & & + & & & + \\
\hline Kaprije & Kaprije & & & & & & & & & & & + & & & + & & & + \\
\hline Krapanj & Krapanj & & & & & + & & & & & & + & & & & & & \\
\hline Zlarin & Zlarin & & & & & + & & & + & & & + & & & + & & & + \\
\hline Žirje & Žirje & & & & & & & & & & & & & & & & & + \\
\hline \multirow{2}{*}{ Prvić } & Prvić Luka & & & & & & & & & & & + & & & & & & + \\
\hline & Prvić Šepurine & & & & & + & & & & & & + & & & & & & + \\
\hline Kornat & Kornati & & & & & & & & & & & & & & & & & \\
\hline \multirow{4}{*}{ Murter } & Murter & & & & + & , & + & & + & + & + & + & + & & + & + & & + \\
\hline & Betina & & & & & + & & & & & & + & & & + & & & + \\
\hline & Jezera & & & & & + & & & & + & & + & & & + & & & + \\
\hline & Tisno & & & & + & & + & & + & + & + & + & & & + & + & + & + \\
\hline \multirow{21}{*}{ Hvar } & Brusje & & & & & & & & & & & & & & & & & + \\
\hline & Hvar & + & + & & + & & + & + & + & + & + & + & & & + & + & + & + \\
\hline & Jagodna & & & & & & & & & & & & & & & & & \\
\hline & Malo Grablje* & & & & & & & & & & & & & & & & & \\
\hline & Milna & & & & & & & & & & & & & & & & & \\
\hline & Sveta Nedjelja & & & & & + & & & & & & & & & & & & \\
\hline & Velo Grablje & & & & & & & & & & & & & & & & & \\
\hline & Zaraće & & & & & & & & & & & & & & & & & \\
\hline & Dol & & & & & + & & & & & & & & & & & & \\
\hline & Rudina & & & & & & & & & & & & & & & & & \\
\hline & Selca kod SG & & & & & & & & & & & & & & & & & \\
\hline & Stari Grad & & & + & + & & + & + & + & + & + & + & & + & + & & & + \\
\hline & Vrbanj & & & & & + & & & & & & & & & & & & + \\
\hline & Gdinj & & & & & & & & & & & & & & & & & + \\
\hline & Gromin Dolac & & & & & & & & & & & & & & & & & \\
\hline & Humac* & & & & & & & & & & & & & & & & & \\
\hline & Ivan Dolac & & & & & & & & & & & & & & & & & \\
\hline & Jelsa & & & & + & & + & + & + & + & + & + & & & + & + & & + \\
\hline & Pitve & & & & & & & & & & & & & & & & & \\
\hline & Poljica & & & & & & & & & & & & & & & & & \\
\hline & Svirče & & & & & + & & & & & & & & & & & & \\
\hline
\end{tabular}




\begin{tabular}{|c|c|c|c|c|c|c|c|c|c|c|c|c|c|c|c|c|c|c|}
\hline \multirow{2}{*}{ Otok } & \multirow{2}{*}{ Naselje } & \multicolumn{4}{|c|}{ 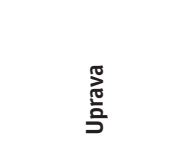 } & \multicolumn{3}{|c|}{ 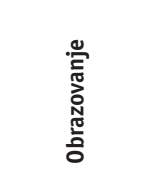 } & \multicolumn{3}{|c|}{ 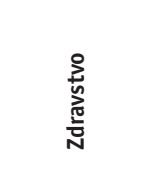 } & \multicolumn{3}{|c|}{ 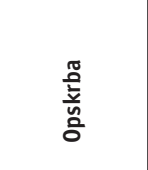 } & \multicolumn{3}{|c|}{ 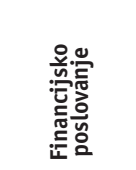 } & \multirow{2}{*}{ 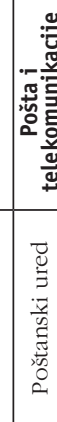 } \\
\hline & & $\begin{array}{l}\frac{\pi}{\tilde{J}} \\
\frac{0}{0} \\
2\end{array}$ & 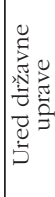 & 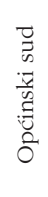 & 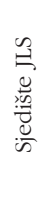 & 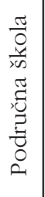 & $\begin{array}{l}\frac{\pi}{0} \\
\frac{d}{x p} \\
\tilde{3} \\
5 \\
0 \\
0 \\
0 \\
0\end{array}$ & $\begin{array}{l}\frac{\pi}{0} \\
\frac{\pi}{x} \\
\frac{\pi}{E} \\
\frac{0}{0} \\
\dot{0}\end{array}$ & 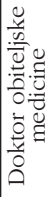 & 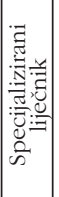 & 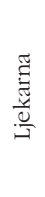 & 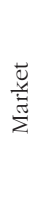 & 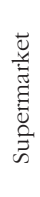 & 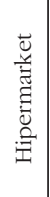 & 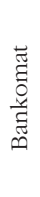 & 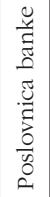 & $\underset{c}{\overleftrightarrow{c}}$ & \\
\hline \multirow{7}{*}{ Hvar } & Vrboska & & & & & + & & & & & & + & & & + & & & + \\
\hline & Vrisnik & & & & & & & & & & & & & & & & & \\
\hline & Zastražišće & & & & & + & & & & & & & & & & & & + \\
\hline & Zavala & & & & & & & & & & & & & & & & & \\
\hline & Sućuraj & & & & + & & + & & + & & & & & & + & & & + \\
\hline & Bogomolje & & & & & + & & & & & & & & & & & & + \\
\hline & Selca kod Bogomolja & & & & & & & & & & & & & & & & & \\
\hline \multirow{6}{*}{ Čiovo } & Okrug Donji & & & & & & & & & & & & & & & & & \\
\hline & Okrug Gornji & & & & + & + & & & + & + & + & + & & & + & & & + \\
\hline & Slatine & & & & & & + & & + & & & + & & + & + & & & + \\
\hline & Arbanija & & & & & & & & & & & + & + & & + & & & \\
\hline & Mastrinka & & & & & & & & & & & + & & & & & & \\
\hline & Žedno & & & & & & & & & & & + & + & & & & & \\
\hline Drvenik Mali & Drvenik Mali & & & & & & & & & & & + & & & & & & \\
\hline Drvenik Veliki & Drvenik Veliki & & & & & & & & + & & & + & & & + & & & + \\
\hline \multirow{18}{*}{ Vis } & Dračevo Polje & & & & & & & & & & & & & & & & & \\
\hline & Marinje Zemlje & & & & & & & & & & & & & & & & & \\
\hline & Milna & & & & & & & & & & & & & & & & & \\
\hline & Plisko Polje & & & & & & & & & & & & & & & & & \\
\hline & Podselje & & & & & & & & & & & & & & & & & \\
\hline & Podstražje & & & & & & & & & & & + & & & & & & \\
\hline & Rogačić & & & & & & & & & & & & & & & & & \\
\hline & Rukavac & & & & & & & & & & & & & & & & & \\
\hline & Vis & + & + & & + & & + & + & + & + & + & + & & & + & + & + & + \\
\hline & Borovik & & & & & & & & & & & & & & & & & \\
\hline & Duboka & & & & & & & & & & & & & & & & & \\
\hline & Komiža & & & & + & & + & & + & + & + & + & & & + & + & & + \\
\hline & Oključna* & & & & & & & & & & & & & & & & & \\
\hline & Palagruža* & & & & & & & & & & & & & & & & & \\
\hline & Podhumlje & & & & & & & & & & & & & & & & & \\
\hline & Podšpilje & & & & & & & & & & & & & & & & & + \\
\hline & Sveti Andrija* & & & & & & & & & & & & & & & & & \\
\hline & Žena Glava & & & & & & & & & & & & & & & & & \\
\hline Biševo & Biševo & & & & & & & & & & & & & & & & & \\
\hline
\end{tabular}




\begin{tabular}{|c|c|c|c|c|c|c|c|c|c|c|c|c|c|c|c|c|c|c|}
\hline \multirow{2}{*}{ Otok } & \multirow{2}{*}{ Naselje } & \multicolumn{4}{|c|}{ 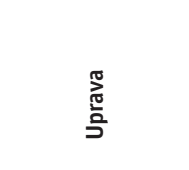 } & \multicolumn{3}{|c|}{ 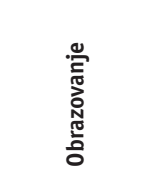 } & \multicolumn{3}{|c|}{ 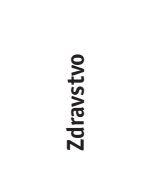 } & \multicolumn{3}{|c|}{ 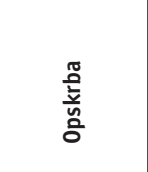 } & \multicolumn{3}{|c|}{ 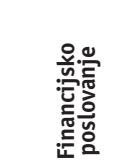 } & \multirow{2}{*}{ 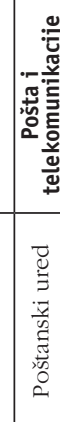 } \\
\hline & & $\begin{array}{l}\frac{\pi}{\vec{J}} \\
: \overline{0} \\
0\end{array}$ & 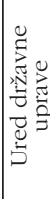 & 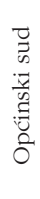 & 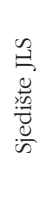 & 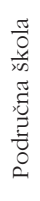 & $\begin{array}{l}\frac{\pi}{0} \\
\frac{d}{x p} \\
\tilde{3} \\
5 \\
0 \\
0 \\
0 \\
0\end{array}$ & $\begin{array}{l}\frac{\pi}{0} \\
\frac{0}{20} \\
\frac{\pi}{\pi} \\
\frac{\pi}{0} \\
\tilde{n} \\
\dot{n}\end{array}$ & 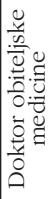 & 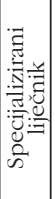 & 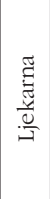 & 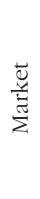 & 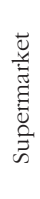 & 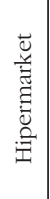 & 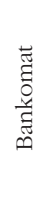 & 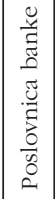 & $\underset{\mathrm{Z}}{\overleftrightarrow{\mathrm{I}}}$ & \\
\hline \multirow{22}{*}{ Brač } & Mirca & & & & & & & & & & & + & & & & & & \\
\hline & Splitska & & & & & & & & & & & + & & & & & & \\
\hline & Supetar & + & + & + & + & & + & + & + & + & + & + & + & + & + & + & + & + \\
\hline & Škrip & & & & & & & & & & & + & & & & & & \\
\hline & Bol & & & & + & & + & + & & + & + & + & + & & + & + & & + \\
\hline & Murvica & & & & & & & & & & & & & & & & & \\
\hline & Dol & & & & & & & & & & & + & & & & & & \\
\hline & Postira & & & & + & & + & & + & + & + & + & & & + & & & + \\
\hline & Gornji Humac & & & & & + & & & & & & + & & & & & & + \\
\hline & Pražnica & & & & & + & & & & & & & + & & & & & + \\
\hline & Pučišća & & & & + & & + & + & + & & & + & & & + & & & + \\
\hline & Bobovišća & & & & & & & & & & & & & & & & & \\
\hline & Ložišća & & & & & & & & & & & & & & & & & + \\
\hline & Milna & & & & + & & + & & + & & + & + & & & + & & & + \\
\hline & Donji Humac & & & & & & & & & & & + & & & & & & \\
\hline & Dračevica & & & & & & & & & & & + & & & & & & \\
\hline & Nerežišća & & & & + & + & & & & & & + & & & + & & & + \\
\hline & Novo Selo & & & & & & & & & & & & + & & & & & \\
\hline & Povlja & & & & & & & & & & & + & & & & & & \\
\hline & Sumartin & & & & & + & & & & & & + & & & + & & & + \\
\hline & Selca & & & & + & & + & & + & + & + & + & & & + & & & + \\
\hline & Sutivan & & & & + & + & & & + & & & + & & & + & & & + \\
\hline \multirow{8}{*}{ Šolta } & Donje Selo & & & & & & & & & & & & & & & & & \\
\hline & Gornje Selo & & & & & & & & & & & + & & & & & & \\
\hline & Grohote & & & & + & + & & + & + & + & + & + & & & + & & & + \\
\hline & Maslinica & & & & & & & & & & & + & & & & & & \\
\hline & Nečujam & & & & & & & & & & & + & & & & & & \\
\hline & Rogač & & & & & & & & & & & & & & + & & & \\
\hline & Srednje Selo & & & & & & & & & & & & & & & & & \\
\hline & Stomorska & & & & & & & & & & & + & & & + & & & + \\
\hline Koločep & Koločep & & & & & + & & & & & & + & & & + & & & + \\
\hline Lopud & Lopud & & & & & + & & & + & + & & + & & & + & & & + \\
\hline \multirow{2}{*}{ Šipan } & Suđurad & & & & & + & & & & & & + & & & & & & \\
\hline & Šipanska Luka & & & & & + & & & + & & & + & & & + & & & + \\
\hline
\end{tabular}




\begin{tabular}{|c|c|c|c|c|c|c|c|c|c|c|c|c|c|c|c|c|c|c|}
\hline \multirow{2}{*}{ Otok } & \multirow{2}{*}{ Naselje } & \multicolumn{4}{|c|}{ 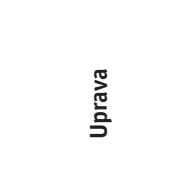 } & \multicolumn{3}{|c|}{ 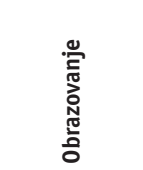 } & \multicolumn{3}{|c|}{ 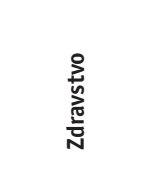 } & \multicolumn{3}{|c|}{ 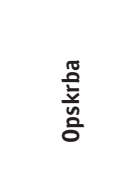 } & \multicolumn{3}{|c|}{ 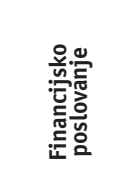 } & \multirow{2}{*}{ 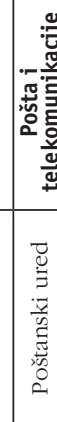 } \\
\hline & & $\begin{array}{l}\frac{\pi}{\tilde{J}} \\
\frac{0}{0} \\
2\end{array}$ & 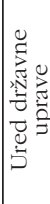 & 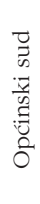 & 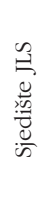 & $\begin{array}{l}\frac{\pi}{0} \\
\frac{\pi}{10} \\
\frac{\pi}{0} \\
0 \\
\frac{0}{0} \\
0 \\
0\end{array}$ & $\begin{array}{l}\frac{\pi}{0} \\
\frac{d}{10} \\
\tilde{y} \\
0 \\
0 \\
0 \\
0 \\
0\end{array}$ & 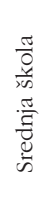 & 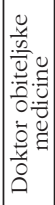 & 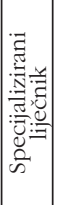 & 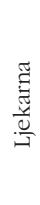 & 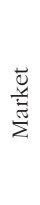 & 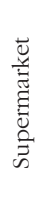 & 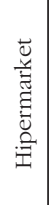 & 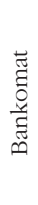 & 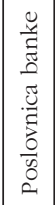 & 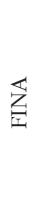 & \\
\hline \multirow{10}{*}{ Korčula } & Čara & & & & & + & & & + & & & + & & & & & & + \\
\hline & Korčula & + & + & + & + & & + & + & + & + & + & + & & + & + & + & + & + \\
\hline & Pupnat & & & & & + & & & & & & + & & & & & & + \\
\hline & Račišće & & & & & + & & & & & & + & & & & & & + \\
\hline & Žrnovo & & & & & & + & & & & & + & & & & & & + \\
\hline & Blato & & & & + & & + & + & + & + & + & + & & & + & + & + & + \\
\hline & Potirna & & & & & & + & & & & & & & & & & & \\
\hline & Lumbarda & & & & + & & & & & & & + & + & & + & & & + \\
\hline & Smokvica & & & & + & + & & & + & + & + & + & & & + & + & & + \\
\hline & Vela Luka & & & & & & + & & + & + & + & + & & + & + & + & + & + \\
\hline \multirow{7}{*}{ Lastovo } & Glavat* & & & & & & & & & & & & & & & & & \\
\hline & Lastovo & + & + & & + & & + & & + & + & + & + & & & + & + & + & + \\
\hline & Pasadur & & & & & & & & & & & & & & & & & \\
\hline & Skrivena Luka & & & & & & & & & & & & & & & & & \\
\hline & Sušac* & & & & & & & & & & & & & & & & & \\
\hline & Uble & & & & & & & & & & & + & & & + & & & + \\
\hline & Zaklopatica & & & & & & & & & & & & & & & & & \\
\hline \multirow{14}{*}{ Mljet } & Babino Polje & & & & + & & + & & + & & + & + & & & & & & + \\
\hline & Blato & & & & & & & & & & & & & & & & & \\
\hline & Goveđari & & & & & + & & & + & + & & + & & & & & & + \\
\hline & Korita & & & & & & & & & & & & & & & & & \\
\hline & Kozarica & & & & & & & & & & & & & & & & & \\
\hline & Maranovići & & & & & & & & & & & & & & & & & \\
\hline & Okuklje & & & & & & & & & & & & & & & & & \\
\hline & Polače & & & & & & & & & & & + & & & + & & & \\
\hline & Pomena & & & & & & & & & & & & & & + & & & \\
\hline & Prožura & & & & & & & & & & & & & & & & & \\
\hline & Prožurska Luka & & & & & & & & & & & & & & & & & \\
\hline & Ropa & & & & & & & & & & & & & & & & & \\
\hline & Saplunara & & & & & & & & & & & & & & & & & \\
\hline & Sobra & & & & & & & & & & & + & & & + & & & \\
\hline
\end{tabular}


Veni Marinković

Cluster for Eco-social Innovation and Development - CEDRA Split, Croatia

e-mail: marinkovic.veni@yahoo.com

\title{
Spatial Development Processes of Croatian Islands - the Analysis of Island Settlements in Terms of the Quantity and Quality of their Central Functions
}

\begin{abstract}
The paper analyses Croatian island settlements in terms of the quantity and quality of their central functions. It examines spatial development processes in relation to the centrality degree and includes 303 settlements on 47 islands. Central functions are analysed in six basic groups: administration, healthcare, education, post and telecommunications, supply and financial operations, within which the hierarchically ranked facilities are considered. The settlements are then classified according to the (non)existence of specific facilities in 5 groups: "No centrality", "Insufficient centrality", "3rd rank centrality", "2nd rank centrality" and "1st rank centrality" and analysed with regard to their position, population change index and age index. The main spatial development processes of Croatian islands are presented. They are manifested in the population polarisation and island littoralisation, as well as unfavourable trends in smaller and poorly equipped settlements.
\end{abstract}

Key words: islands, central functions, centrality of settlements, polarisation, littoralisation. 